\title{
Tannins and Anthocyanins: From Their Origin to Wine Analysis - A Review
}

\author{
A.P. Nel \\ Department of Agriculture, Faculty of Applied Science, Cape Peninsula University of Technology (CPUT), Wellington campus
}

Submitted for application: January 2017

Accepted for publication: October 2017

Key words: Metabolic pathways, tannins, anthocyanins, analytical methods

\begin{abstract}
Anthocyanins and tannins are very important chemical compounds in the grape berry and the corresponding wine, as they greatly influence the colour, taste and maturation potential of the wine, as well as offer numerous health benefits. This review tries to establish the origin of anthocyanins and tannins by looking at metabolic pathways and attempting to establish a link between photosynthesis and the flavonoid biosynthetic pathway, the translocation thereof from leaves to berries, different methods to extract anthocyanins and tannins from wine and, in the end, the different analytical methods that can be used to analyse for anthocyanins and tannins.
\end{abstract}

\section{INTRODUCTION}

When talking about the origin of tannins and anthocyanins in grapes and wine, the term flavonoid biosynthesis springs to mind. However, the origin of the precursors that enter the flavonoid biosynthetic pathway must first be considered. Everything starts with bud break in the early spring (Coombe, 1995). The grapevine starts to push its leaves into the open and the chlorophyll in the leaves uses sunlight to start photosynthesis. From photosynthesis, the NADP+ molecules are used in the Calvin cycle (Ferrer et al., 2008) to produce erythrose-4-phosphate (Marques et al., 2007). Erythrose-4phosphate condenses with phosphoenolpyruvate to produce phenylalanine in the phenylalanine pathway (Ferrer et al., 2008). In the phenylpropanoid pathway the phenylalanine is deaminated to form chalcone. It is this chalcone that is the precursor for the flavonoid biosynthetic pathway, which synthesises anthocyanins and proanthocyanidins (Bogs et al., 2007).

The word tannin is a collective name for a group of phenols that exist naturally in the grape berry. This group of phenols is further subdivided into flavonoids and nonflavonoids (Monagas et al., 2005). The non-flavonoids consist of the benzoic acids and the cinnamic acids, while the flavonoids consists of flavanols, flavonols and anthocyanins (Monagas et al., 2005). The basic building blocks for tannin come from the flavanol subgroup and consist of $(+)$-catechin, (-)-epicatechin, (-)-epigallocatechin and (-)-epicatechingallate (Schofield et al., 2001; Sarneckis et al., 2006). These building blocks start to polymerise with each other and are then called proanthocyanidins or hydrolysable tannins (Schofield et al., 2001; Sarneckis et al., 2006).

The colour of grapes comes from the anthocyanins. In their most basic form these anthocyanins are called anthocyanidins, but when they bind with glucose, anthocyanins are formed. There are five types of anthocyanins, namely cyanidin, delphinidin, peonidin, petunidin and malvidin. Each of these anthocyanins can also be acylated with coumaric acid and acetate (Monagas et al., 2005).

There are different external factors that will influence the concentration of anthocyanins and tannins in the grape berry. The two external factors that go hand in hand are temperature (Jackson \& Lombard, 1993, Mori et al., 2005; Chorti et al., 2010) and sunlight (Kennedy et al., 2000a; Pastor del Rio $\&$ Kennedy, 2006). If the ambient day temperature is below $17^{\circ} \mathrm{C}$ and the night temperature is below $15^{\circ} \mathrm{C}$ (Jackson \& Lombard, 1993), no anthocyanins will be produced to accumulate, resulting in less colour in the grape berry (Mori et al., 2005; Chorti et al., 2010). Sunlight is also very important as it helps the flavonoid pathway to produce more anthocyanins (Dokoozlian \& Kliewer, 1996). Therefore the row direction and canopy management are very important factors to consider when red grape cultivars are planted. Water is also an important external factor to consider, as too much water will dilute the anthocyanins, resulting in wine with poor colour (Hardie \& Considine, 1976; Matthews \& Anderson, 1988).

Anthocyanins accumulate in the vacuoles of the epidermal cells of the grape berry skin (Ortega-Regules et al., 2006). Anthocyanins are released more easily from the vacuoles than the proanthocyanidins (Ortega-Regules et al., 2006). Proanthocyanidins bind with cell wall components and need enzymes to be released (Arnous \& Meyer, 2010). There are different practices and methods to obtain wine with more colour and tannin structure. Methods like cold soaking/maceration (McMahon et al., 1999, Gómez-Plaza 
et al., 2000; 2001, Álvarez et al., 2009; Gil-Muñoz et al., 2009) could release more colour from grape skins, while post-fermentation maceration (Zimmer et al., 2002) could release more tannins, as the alcohol will help in releasing the tannins. Thermovinification (Lowe et al., 1976, Sacchi et al., 2005; Baiano et al., 2009) and carbonic maceration (GómezMíguez \& Heredia, 2004; Sacchi et al., 2005; Etaio et al., 2008) can also be used to extract anthocyanins and tannins from the skins. These methods will have variable success, as wines made from carbonic maceration will have a lighter colour but will be fruitier (Etaio et al., 2008).

The proanthocyanidin concentration of wine influences the mouthfeel of the wine, especially in terms of astringency and bitterness (Gawel, 1998; Monagas et al., 2005). Furthermore, proanthocyanidins help to stabilise colour (Monagas et al., 2005) when they bind to anthocyanins, and increase maturation potential (Lorenzo et al., 2005).

In order to manage the anthocyanin and tannin levels in wine, one must be able to measure them. There are three main methods to analyse tannins. These are the colorimetric (Schofield et al., 2001), gravimetric (Giner-Chavez et al., 1997) and precipitation methods (Hagerman \& Butler, 1978, Harbertson et al., 2003; Sarneckis et al., 2006). The first and second methods are not commonly used in the wine industry, but the precipitation methods are widely used. These include the MCP (methyl cellulose) (Sarneckis et al., 2006) and BSA (bovine serum albumin) methods (Harbertson et al., 2003). There are also several methods for the analysis of anthocyanins, namely the Iland method for total anthocyanin, the Somers and Evans, and Boulton and Levengood methods for co-pigmentation analysis, and the Ribereau-Gayon and Stonestreet method for determining the concentration of anthocyanins.

This review will follow the metabolic precursors from photosynthesis to flavonoid biosynthesis. Subsequently, the extraction of anthocyanins and proanthocyanidins from the berry into the wine will be discussed. The review will conclude with a discussion of the different analytical methods that can be used for the determination of proanthocyanidins and anthocyanins.

If a berry from any red cultivar is squeezed, it will be noticed that the juice is white and not red. Although most of the red cultivars have white juice, there are cultivars with red juice. These cultivars are called tenturier grapes (Alicante Bouchet, Palas, Roobernet, Jacquez and Pontac). These cultivars are normally used to "colour" other red cultivars if the wine is not red enough.

The main difference between white and red grapes is the colour of their skins. The reason why red grapes' skins are red is because the anthocyanins are found in the skins. Anthocyanins are members of the flavan-3-ols. The main anthocyanins that are found in grape skins are cyanidin, delphinidin, peonidin, petunidin and malvidin (Liang et al., 2008) (Fig. 1). These five basic anthocyanins are acylated to coumaric acid and acetate to ultimately form 15 types of anthocyanins (Gómez-Plaza et al., 2001). The colour depends on the hydroxyl groups on the B-ring of the flavylium cation. These five anthocyanins vary in hue from pink to purple-blue (Castañeda-Ovando et al., 2009).

Anthocyanins only start to accumulate at the onset of véraison. Anthocyanins accumulate in the vacuoles of the epidermal cells of the berry skins (Ortega-Regules et al., 2006). When anthocyanidins form glycosides with glucose, anthocyanins are formed (Castañeda-Ovando et al., 2009).

\section{ORIGINS OF TANNIN AND ANTHOCYANIN PRECUR- SORS}

To understand proanthocyanidins and anthocyanins in wine, it is important to investigate the origin of these compounds. Knowledge on how and where the precursors for proanthocyanidins are synthesised is very important for understanding the ultimate role of proanthocyanidins, and also the role they play in the ripening berry. Understanding the external factors that influence these proanthocyanidins will also help viticulturists in managing the concentration of proanthocyanidins and anthocyanins in the grape berry.

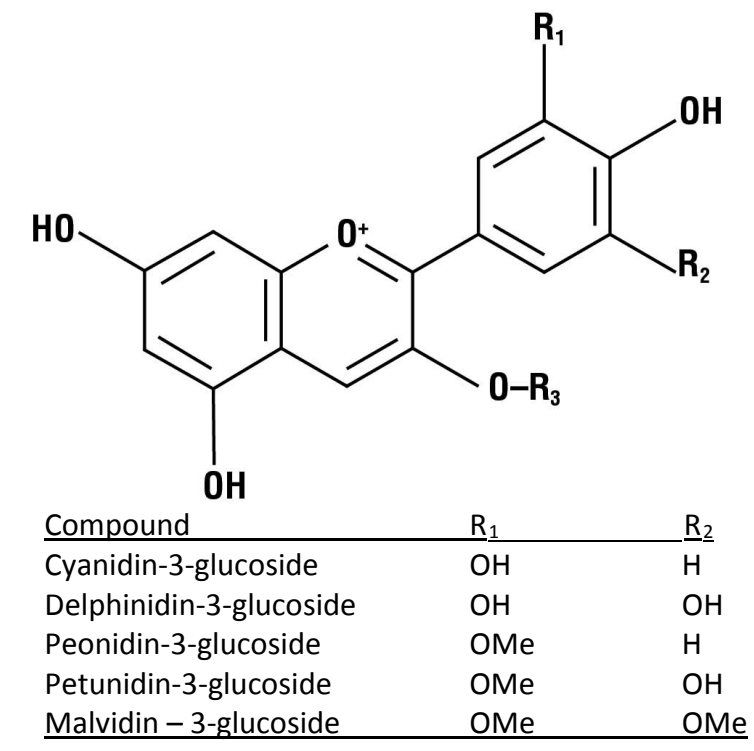

FIGURE 1

The five anthocyanins associated with red colour in wine (with structure) 


\section{Photosynthesis}

It is normally accepted that the state of dormancy is terminated when the mean daily temperature drops below $10^{\circ} \mathrm{C}$ for at least seven consecutive days (Lavee \& May, 1997). After the termination of dormancy, budburst takes about 30 days to occur in Shiraz, 35 days in Mataro (Mourvedre) and 32 days in Grenache (Lavee \& May, 1997).

During the growing season, the vine produces carbohydrates in the form of sugars (more specifically glucose), some of which the vine stores as starch in its shoots (Winkler, 1965; Burger \& Deist, 1981). In the winter this starch is converted to sugar, which prevents the cells from freezing (Winkler, 1965; Burger \& Deist, 1981). Before the next growing season, the vine converts the sugar back to starch (Winkler, 1965; Burger \& Deist, 1981). It is this stored carbohydrates that the vine will use for energy and bud break. This stored energy is used until the vine can start to photosynthesise.

Photosynthesis is a metabolic pathway that converts light energy into chemical energy (Voet \& Voet, 2004) and that takes place in the plastids known as chloroplasts, which are found in the leaves of plants. During photosynthesis, carbon dioxide $\left(\mathrm{CO}_{2}\right)$, which is taken from the air, and water $\left(\mathrm{H}_{2} \mathrm{O}\right)$, which is taken up by the root system, are fixed by sunlight energy (electromagnetic radiation) to yield carbohydrates (a triose phosphate compound called 3-phosphoglycerate, abbreviated as G3P or 3PG, and oxygen $\left(\mathrm{O}_{2}\right)$ (Chen \& Zhang, 2008):

$\mathrm{CO}_{2}+\mathrm{H}_{2} \mathrm{O}+$ light energy $\rightarrow\left(\mathrm{CH}_{2} \mathrm{O}\right)+\mathrm{O}_{2}$

Photosynthesis occurs in two steps:

A light-dependent reaction step (light reaction), in which $\mathrm{H}_{2} \mathrm{O}$ is oxidised and ATP and NADPH are formed (Voet $\&$ Voet, 2004). This occurs when the chlorophyll absorbs sunlight and splits the water molecule $\left(\mathrm{H}_{2} \mathrm{O}\right)$ into hydrogen $\left(\mathrm{H}_{2}\right)$ and oxygen $\left(\mathrm{O}_{2}\right)$. The oxygen molecule is not needed and is released back into the air. The hydrogen dissolves, as a free ion, into the cytoplasm. The energized $\mathrm{e}^{-}$, which was removed from the $\mathrm{H}_{2} \mathrm{O}$ molecule, is passed along an electron transport chain to $\mathrm{NADP}^{+}$, generating $\mathrm{NADPH}$. In the process, ADP is phosphorylised to ATP. Both the NADPH and ATP are used in the Calvin cycle (Jackson, 1994):
$2 \mathrm{H}_{2} \mathrm{O}+2 \mathrm{NADP}^{+}+2 \mathrm{ADP}+2 \mathrm{Pi}+$ sunlight $\rightarrow 2 \mathrm{NADPH}$ $+2 \mathrm{H}^{+}+2 \mathrm{ATP}+\mathrm{O}_{2}$

A light-independent reaction step (dark reaction), in which the high-energy molecules, ATP and NADPH, are used to fixate $\mathrm{CO}_{2}$ to synthesise the precursors for carbohydrates through the Calvin cycle or the reductive pentose phosphate cycle (Voet \& Voet, 2004):

$3 \mathrm{CO}_{2}+9 \mathrm{ATP}+6 \mathrm{NADPH}+6 \mathrm{H}^{+} \rightarrow \mathrm{C}_{3} \mathrm{H}_{6} \mathrm{O}_{3}$-phosphate + $9 \mathrm{ADP}+8 \mathrm{Pi}+6 \mathrm{NADP}^{+}+3 \mathrm{H}_{2} \mathrm{O}$

Therefore it is important to note that photosynthesis is affected by $\mathrm{CO}_{2}$ concentration, temperature, water stress, diseases, humidity and light intensity, as well as the nutrients available in the soil (Hardie \& Considine, 1976; Jackson, 1994).

\section{The Calvin cycle (pentose phosphate cycle)}

The Calvin cycle takes place in the chlorophyll plastid (Kruger \& Von Schaewen, 2003) and consists of two distinct phases. In the first phase, the oxidative phase, two molecules of $\mathrm{NADP}^{+}$are reduced to two molecules of NADPH. The energy for this reaction comes from the conversion of glucose-6-phosphate into ribulose-5-phosphate.

Glucose-6-phosphate $+2 \mathrm{NADP}^{+}+\mathrm{H}_{2} \mathrm{O} \rightarrow$ ribulose-5phosphate $+2 \mathrm{NADPH}+2 \mathrm{H}^{+}+\mathrm{CO}_{2}$

In the second phase, the reductive phase, ribulose-5phosphate is enzymatically reduced (as shown in Table 1) into different metabolites that are used in nucleotide synthesis and phenylpropanoid production (Kruger \& Von Schaewen, 2003; Voet \& Voet, 2004).

\section{Phenylalanine synthesis}

To form the aromatic amino acid phenylalanine, erythrose4-phosphate condenses with phosphoenolpyruvate (PEP), which is obtained from glycolysis, to form chorismate (Fig. 2). In a further three enzymatic reaction steps, chorismate is turned into the aromatic amino acid phenylalanine. Table 2 shows the enzymes that are used to synthesise phenylalanine (Voet \& Voet, 2004).

Up until now it has been shown that, as soon as the vine starts to form leaves (E-L 4 stadium) and to photosynthesise,

TABLE 1

List of enzymes in the pentose phosphate cycle.

\begin{tabular}{lll}
\hline Enzyme & EC number* & Mode of working \\
\hline Phospho-ribulose kinase & 2.7 .1 .19 & Ribulose-5-phosphate + ATP $=$ ribulose-1,5-bisphosphate \\
Ribulose bisphosphate carboxylase & 4.1 .1 .39 & Ribulose-1,5-bisphosphate $+\mathrm{CO}_{2}=3$ - phosphoglycerate \\
Phosphoglycerate kinase & 2.7 .2 .3 & 3-Phosphoglycerate $+\mathrm{ATP}=1,3$ - bisphosphoglycerate \\
Glyceraldehyde-3-phosphate-dehydrogenase & 1.2 .1 .12 & 1,3-Bisphosphoglycerate + NADPH $=$ G-3-phosphate \\
Triose-phosphate isomerase & 5.3 .1 .1 & Glyceraldehyde-3-phosphate $=$ dihydroxyacetonephosphate \\
Aldolase & 4.1 .2 .14 & Dihydroxyacetonephosphate $=$ fructose-1,6-bisphosphate \\
Fructose bisphosphatase & 3.1 .3 .11 & Fructose-1,6-bisphosphate $=$ fructose-6-phosphate \\
Transketolase & 2.2 .1 .1 & Fructose-6-phosphate $=$ erythrose-4- phosphate \\
\hline
\end{tabular}

* Enzyme Commission number 


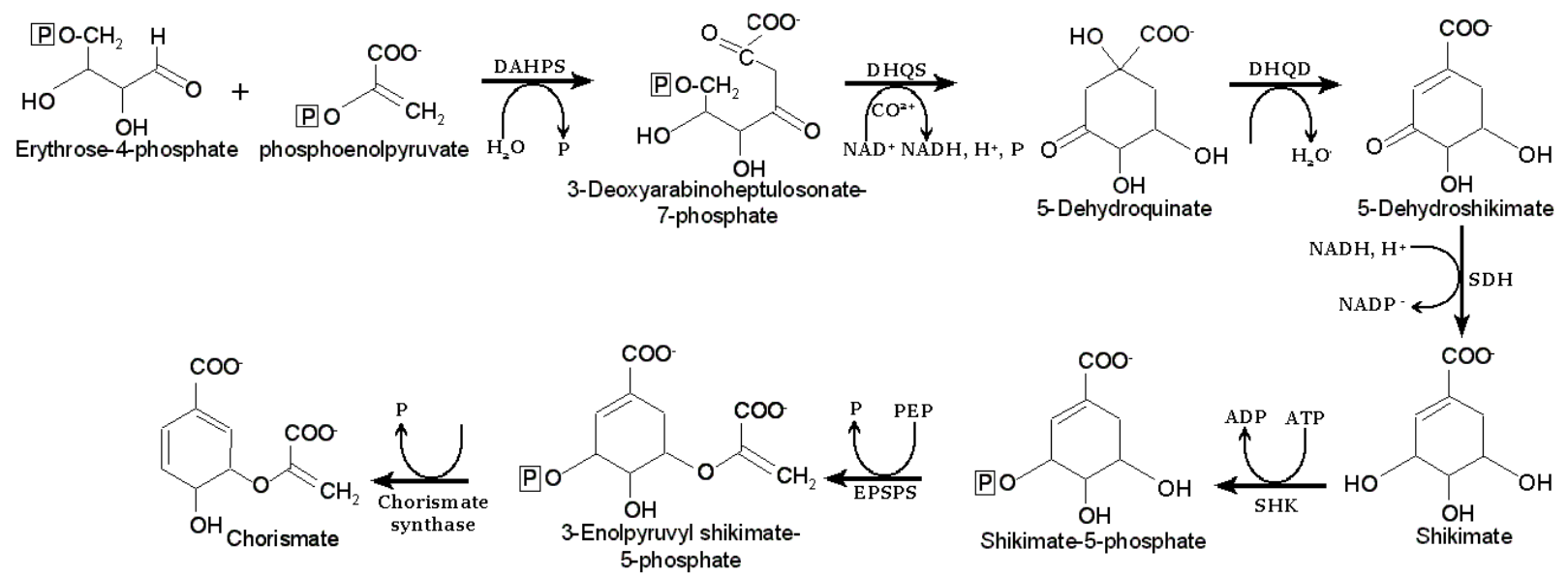

FIGURE 2

Shikimate pathway

Source: http://www.biocristalografia.df.ibilce.unesp.br/pesquisa/shikimate_pathway2.php

TABLE 2

Enzymes in the phenylalanine metabolic pathway.

\begin{tabular}{|c|c|c|}
\hline Enzymes & EC number* & Mode of working \\
\hline $\begin{array}{l}\text { 2-keto-3-deoxy-D-arabinoheptulosanate-7- } \\
\text { phosphate synthase }\end{array}$ & 2.5.1.54 & $\mathrm{PEP}+4 \mathrm{EP}=$ 2-keto-3-deoxyarabinoheptulosonate-7-P \\
\hline Dehydroquinate synthase & 4.2.3.4 & $\mathrm{DAHP}+\mathrm{NAD}+=5$-dehydroquinate \\
\hline 5-Dehydroquinate dehydratase & 4.2.1.10 & 5-Dehydroquinate $=5$-dehydroshikimate \\
\hline Shikimate dehydrogenase & 1.1.1.25 & 5-Dehydroshikimate $+\mathrm{NADH}=$ shikimate \\
\hline Shikimate kinase & 2.7.1.71 & Shikimate + ATP $=$ shikimate-5-phosphate \\
\hline 5-Enolpyruvylshikimate-3-phosphate synthase & 2.5.1.19 & $\begin{array}{l}\text { Shikimate-5-phosphate }=5 \text { - enolpyruvylshikimate-3- } \\
\text { phosphate }\end{array}$ \\
\hline Chorismate synthase & 4.2.3.5 & 5-Enolpyruvylshikimate-3-phosphate $=$ chorismate \\
\hline Chorismate mutase & 5.4.99.5 & Chorismate $=$ prephenate \\
\hline Prephenate dehydratase & 4.2.1.51 & Prephenate $=$ phenylpyruvate \\
\hline Aminotransferase & 2.6.1.1 & Phenylpyruvate $=$ phenylalanine \\
\hline
\end{tabular}

* Enzyme Commission number

the vine begin to synthesise metabolites that it can use during its growing stage. These metabolites will not just give the plant the energy to grow, but also help to protect it against foraging by herbivores (Jaakola et al., 2002; Bogs et al., 2005; 2007).

The synthesis of phenylalanine only occurs in plants and microorganisms, and therefore this pathway is a natural target for herbicides that will not be toxic to humans, animals and birds. For instance, the active ingredient of Round-Up is glyphosate $\left(\mathrm{C}_{3} \mathrm{H}_{8} \mathrm{NO}_{5} \mathrm{P}\right)$, which inhibits the formation of 5-enolpyruvylshikimate-3-phosphate by plants (Marques et al., 2007). Necessary amino acids cannot be formed and therefore the plant dies (Voet \& Voet, 2004).

The synthesis of chorismate is also known as the shikimate pathway. Although the original advantage of the phenylpropanoid pathway is still obscure, further studies have shown that the phenylpropanoids serve as key chemical modulators for plant communication with insects and microbes, playing attractive (berry colour) as well as repellent (phytoalexin responses) roles. The product of the phenylpropanoid pathway is the flavonoids, which give the plant protection against the harmful UV rays of the sun, as well as making the plant unappetising for herbivores to eat (Ferrer et al., 2008).

\section{Phenylpropanoid pathway}

The first part of the phenylpropanoid pathway consists of three enzymatic steps. In the first of the enzymatic steps (as shown in Table 3), phenylalanine is deaminated by the enzyme phenylalanine ammonia lyase (PAL) to form cinnamic acid. A second enzyme, cinnamic acid-4hydroxylase $(\mathrm{C} 4 \mathrm{H})$, catalyses the introduction of a hydroxyl 
group $(-\mathrm{OH})$ at the para position of the phenyl ring to form p-coumaric acid. Then a third enzyme, p-coumaric:CoA ligase (4CL), combines a co-enzyme (CoA) with the p-coumaric acid to form the p-coumaroyl-CoA. Chalcone synthase (CHS) catalyses the condensation and also the subsequent intermolecular cyclisation of three acetate units onto the p-coumaroyl-CoA (Ferrer et al., 2008). The full phenylpropanoid pathway is shown in Fig. 3.

From here, the chalcone will be part of the flavonoid biosynthetic pathway, from where all of the flavonoids are derived. Only the flavonoids that are relevant to this research will be mentioned in this review.

\section{Flavonoid biosynthetic pathway}

The final biosynthetic pathway for flavonoids is the flavonoid biosynthetic pathway (Fig. 4). During this pathway, chalcone is isomerised into naringenin by the chalcone isomerase (CHI) enzyme (Boss et al., 1996; Winkel-Shirley, 2001). This naringenin is a flavanone. A hydroxyl (-OH) group is then introduced, which binds to the naringenin with the help of the enzyme flavanoid-3- $\beta$-hydroxylase $(\mathrm{F} 3 \mathrm{H})$ to form a dehydrokaempferol (Winkel-Shirley, 2001). By further enzymatic reactions (Table 4), the basic building blocks for proanthocyanidins (catechins and epicatechins) and anthocyanidins are formed.

\section{TRANSLOCATION AND DEVELOPMENT OF TANNIN AND ANTHOCYANIN}

Flavonoid synthesis takes place inside the berry, as the berry is a sink for minerals and monosaccharides (Coombe, 1992). The berry has two important organs in which flavonoid metabolites can accumulate, viz. the skin and the seed of the berry.

There are two classes of genes that are required for biosynthesis, namely the structural genes (the genes encoding the enzymes that directly participate) and the regulatory genes (the genes that control the transcription of the structural genes). Therefore the enzyme activity in the various pathways is highly regulated (Jaakola et al., 2002).

According to a study done by Bogs et al. (2007), the grapevine transcription factor VvMYBPA1 helps to regulate two of the structural genes (LAR and ANR) in the flavonoid biosynthetic pathway that catalyse the transformation of proanthocyanidins and anthocyanidins. They found that the development of the grape berry occurs in two stages. In the first stage, which is from flowering to véraison, VvMYBPA1 regulates the synthesis of proanthocyanidins (PA). In the second stage, the onset of ripening, VvMYBA1 regulates anthocyanidin synthesis (Bogs et al., 2005; 2007).

\section{ANTHOCYANIN IN THE GRAPE SKIN}

There are five basic anthocyanins, which are shown in Fig. 1. These anthocyanins accumulate in the vacuoles in the upper cellular layers of the hypodermis of the berry skin (GonzálesNeves et al., 2008).

The total amount of anthocyanins at harvest depends on a couple of agro-economic factors, including variety, environmental factors (e.g. climate) and agronomical practices (e.g. pruning, irrigation, canopy management, etc.) (Río Segade et al., 2008; Rolle et al., 2009). The tannins and anthocyanins form different complexes with the cell wall components during berry development (Geny et al., 2003). As the berry ripens, these complexes are broken down more easily than in unripe berries.

The transcription factor, VvMYBA, is normally switched off before véraison and only starts to express after véraison (Bogs et al., 2005; 2007). VvMYBA encodes the LDOX enzyme, which catalyses the synthesis of anthocyanin (Bogs et al., 2005; 2007) with UFGT, which is encoded by VvUFGT (Bogs et al., 2005). Anthocyanin synthesis occurs after proanthocyanidin accumulation is completed (Downey et al., 2003; Bogs et al., 2005; 2007).

It therefore is evident that the anthocyanins are synthesised in the berry at the beginning of véraison. The anthocyanidins then bind with a glucose molecule, which is transported to the berry via phloem sap flow (Coombe, 1992) to form anthocyanin. The anthocyanins are then translocated to the vacuoles of the epidermal cells of the grape berry skin.

Thus the highest concentration of proanthocyanidins (Fig. 1) occurs just before véraison, with a decrease until harvest. Although the total tannin concentration can be higher in seeds than in skins, the polymer length is found to be higher in the skins (Downey et al., 2003). The seed procyanidins are therefore more astringent than skin proanthocyanidins to deter animals from eating the berries before ripening.

\section{PHENOLIC RIPENESS AND EXTRACTABILITY OF ANTHOCYANINS INTO WINE}

The accumulation of anthocyanins and tannins in the developing grape berry is very complex. Research on the phenolic ripeness and extraction of anthocyanins and tannins was done by Glories (1984a; 1984b) and is very important to winemakers today (Kennedy et al., 2000b; Herderich

TABLE 3

The enzymes in the first part of the phenylpropanoid pathway.

\begin{tabular}{lll}
\hline Enzymes & EC number* & Mode of working \\
\hline Phenylalanine ammonia lyase & 4.3 .1 .5 & Phenylalanine $=$ cinnamic acid \\
Cinnamic acid 4-hydroxylase & & Cinnamic acid $=$ p-coumaric acid \\
p-coumaroyl-CoA ligase & & p-coumaric acid + CoA $=$ p-coumaroyl-CoA \\
Chalcone synthase & 2.3 .1 .74 & p-coumaroyl-CoA + malonyl- CoA $=$ chalcone \\
\hline
\end{tabular}

* Enzyme Commission number 
PHENYLALANINE METABOLISM

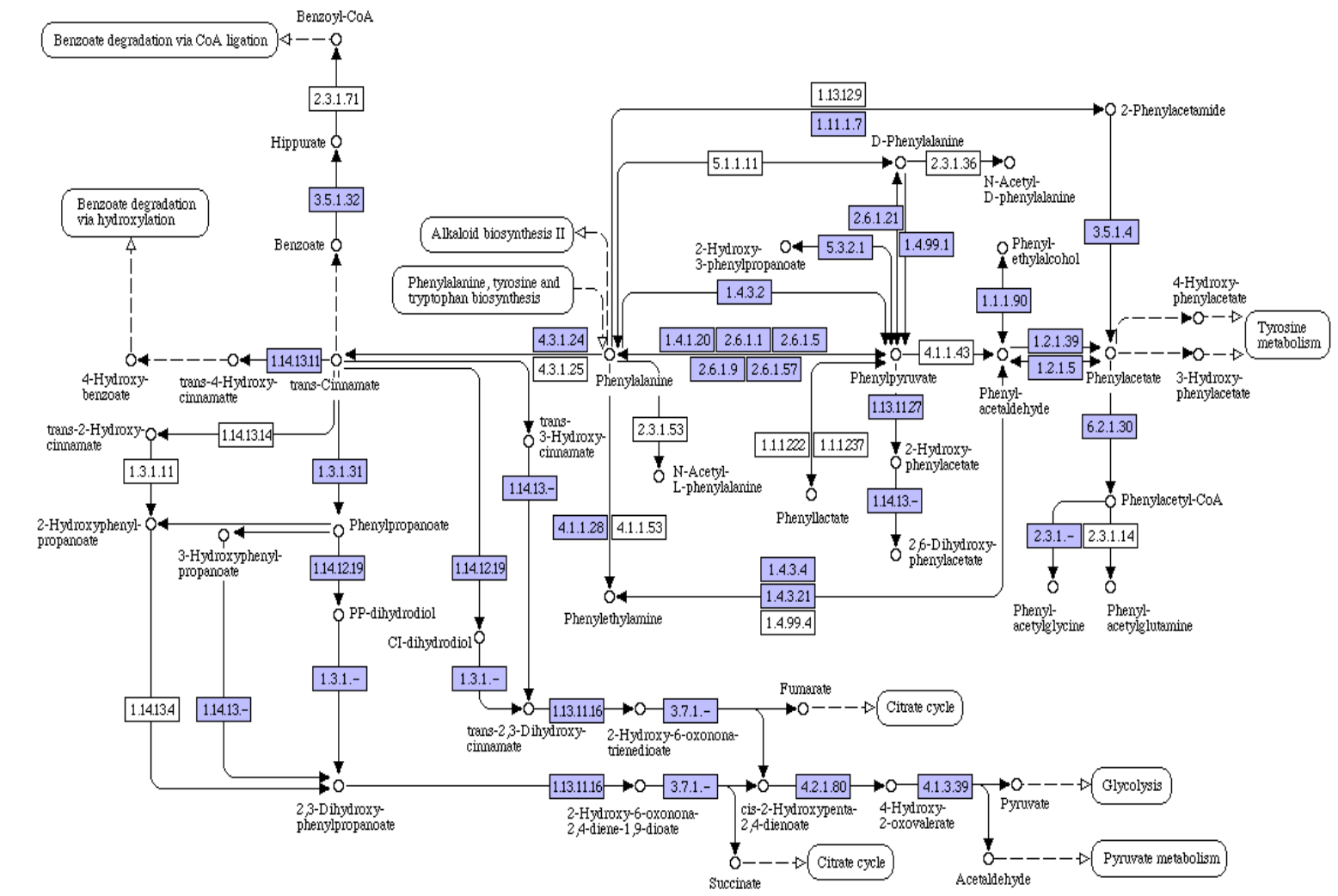

003609111108

(c) Kanehisa Laboratonies

FIGURE 3

A schematic overview of the phenylpropanoid pathway in the grapevine

Source: http://hultgren.wustl.edu/UTI89/map-nolabel/map00360.html

TABLE 4

The enzymes of the flavonoid biosynthetic pathway.

\begin{tabular}{|c|c|c|c|}
\hline Enzymes & EC number* & Genes & Mode of working \\
\hline Chalcone isomerase & 5.5 .1 .6 & $\mathrm{VvCHI}$ & Narengenin chalcone $=$ naringenin \\
\hline Flavanone-3- $\beta$-hydroxylase & & & Naringenin $=$ dihydrokaempferol \\
\hline Flavonoid-3'-hydroxylase & & & Dihydrokaempferol $=$ dihydroquercitin \\
\hline Flavonoid-3',5'-hydroxylase & & VvF3'5'H1 & Dihydrokaempferol $=$ dihydromyricetin \\
\hline Flavonol synthase & & & $\begin{array}{l}\text { Dihydroquercetin/dihydromyricetin = } \\
\text { dihydroquercetin/dihydromyricetin }\end{array}$ \\
\hline Dihydroflavonol-4-reductase & 1.1.1.219 & & $\begin{array}{l}\text { Reduces the dihydroflavonols to } \\
\text { leucoanthocyanidins }\end{array}$ \\
\hline Leucoanthocyanidin reductase & & VvLAR1 & $\begin{array}{l}\text { Reduction of the leucoanthocyanidin to its } \\
\text { corresponding anthocyanin }\end{array}$ \\
\hline Leucoanthocyanidindioxygenase & & VvLDOX & Catalyses the synthesis of anthocyanins \\
\hline Anthocyanidin synthase & & & Leucocyanidin/-delphinidin = cyanidin/delphinidin \\
\hline Anthocyanidin reductase & 1.3 .1 .77 & VVANR & Cyanidin $=$ epicatechin \\
\hline UDP-Glc:flavonoid-3-O & & & $\begin{array}{l}\text { Cyanidin/delphinidin }=\text { different anthocyanins- } \\
\text { glucosyltransferase }\end{array}$ \\
\hline Methyltransferase & 2.1.1.6 & VvANR & $\begin{array}{l}\text { Glucosylation of glucose to the Glucosylation of } \\
\text { glucose to the }\end{array}$ \\
\hline
\end{tabular}

* Enzyme Commission number 


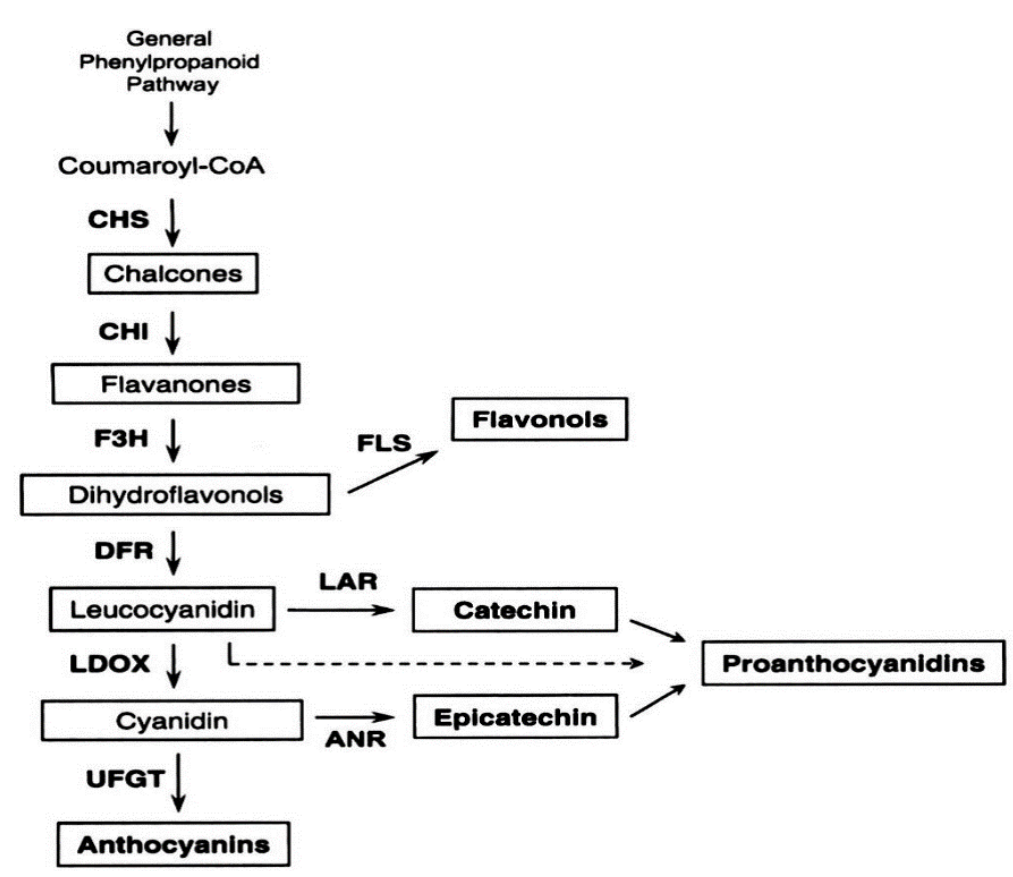

FIGURE 4

The flavonoid biosynthetic pathway. The enzymes that are involved in the pathway are as follows: CHS - chalcone synthase, CHI - chalcone isomerase, F3H - flavanone-3- $\beta$-hydroxylase, FLS - flavonol synthase, DFR - dihydroflavonol-4-reductase, LAR - leucoanthocyanidin reductase, LDOX - leucoanthocyanidin dioxygenase, ANR - anthocyanidin reductase, and UFGT - UDP-Glc:flavonoid-3-O-glycosyltransferase (Bogs et al., 2007).

et al., 2001; Kennedy et al., 2001, Harbertson et al., 2002; Herderich et al., 2005; Romero-Cascales et al., 2005; Ortega-Regules et al., 2006; Río Segade et al., 2008; Rolle et al., 2009). Fig. 6 shows the development of the grape berry and the accumulation of anthocyanins and tannins from flowering up until harvesting.

\section{EXTRACTABILITY ACCORDING TO THE GLORIES METHOD}

From the time the first grapevine was planted, in Anatolia in approximately $8000 \mathrm{BC}$ (McGovern, 2005), methods to achieve ripeness as soon as possible have been employed. There are different ways to test whether the grapes are ripe enough, although the easiest way is to taste the grapes to find out if they are sweet enough to pick and eat. Modernday winemakers use analytical methods to predict ripeness. According to Bisson (2001), grape maturity can be defined as the physiological age of the berry on the vine. Thus, phenological ripeness will differ from cultivar to cultivar.

Glories (1984a; 1984b), from France, established an assay to measure the extractability of the anthocyanin from the grape berry skin. The following formula is used by Glories $(1984 a ; 1984 b)$ to determine the percentage extractability, where $\mathrm{d} 1$ is the total anthocyanins at $\mathrm{pH} 1, \mathrm{~d} 2$ is the extractable anthocyanins at $\mathrm{pH} 3.2$, tt1 is a test tube with $\mathrm{pH} 1$ solution and distilled water, $\mathrm{tt} 2$ is a test tube with $\mathrm{pH} 1$ solution and metabisulfite solution, $\mathrm{tt} 3$ is a test tube with $\mathrm{pH} 3.2$ solution and distilled water, $\mathrm{tt} 4$ is a test tube with $\mathrm{pH} 3.2$ solution and metabisulfite solution, and EA\% is the percentage extractability:
- $\quad d 1=(t t 1-t t 2) * 875 * 2$

- $\quad d 2=(t t 3-t t 4) * 875 * 2$

- $\quad$ Total anthocyanin $(\mathrm{mg} / \mathrm{L})=(\mathrm{tt} 1-\mathrm{tt} 2) * 875 * 100$

- $E A \%=[(d 1-d 2) / d 1] * 100$

- $\quad$ Skin tannin $=A_{280}^{p H 3.2 * 40}$

In this method, the absorbance of the anthocyanin of homogenised grapes is measured at $520 \mathrm{~nm}$ at wine $\mathrm{pH}$ (which for this method is $\mathrm{pH} 3.2$ ) and at $\mathrm{pH} 1$. At this low $\mathrm{pH}$ the cell walls are ruptured and the anthocyanin is extracted. The difference between $\mathrm{pH} 1$ and $\mathrm{pH} 3.2$ gives the extractability. The lower the values between $\mathrm{d} 1$ and $\mathrm{d} 2$, the smaller the difference between these two measurements and the more easily extractable the anthocyanins are. The values are normally between $20 \%$ and $70 \%$,where values smaller than $40 \%$ are considered to be an indication of phenolic ripeness. The values will differ between different cultivars. The lower the value, the more easily the anthocyanins will be extracted.

The thickness of the skins differs between cultivars, so the values for extractability will differ from cultivar to cultivar. Studies done by Río Segade et al. (2008) and Rolle et al. (2009) have shown that the thickness of the berry skin has a large influence on the extraction of anthocyanins. Table 5 shows eight cultivars that were tested by Río Segade et al. (2008), and more anthocyanin was extracted from cultivars with thicker skins than from cultivars with thinner 


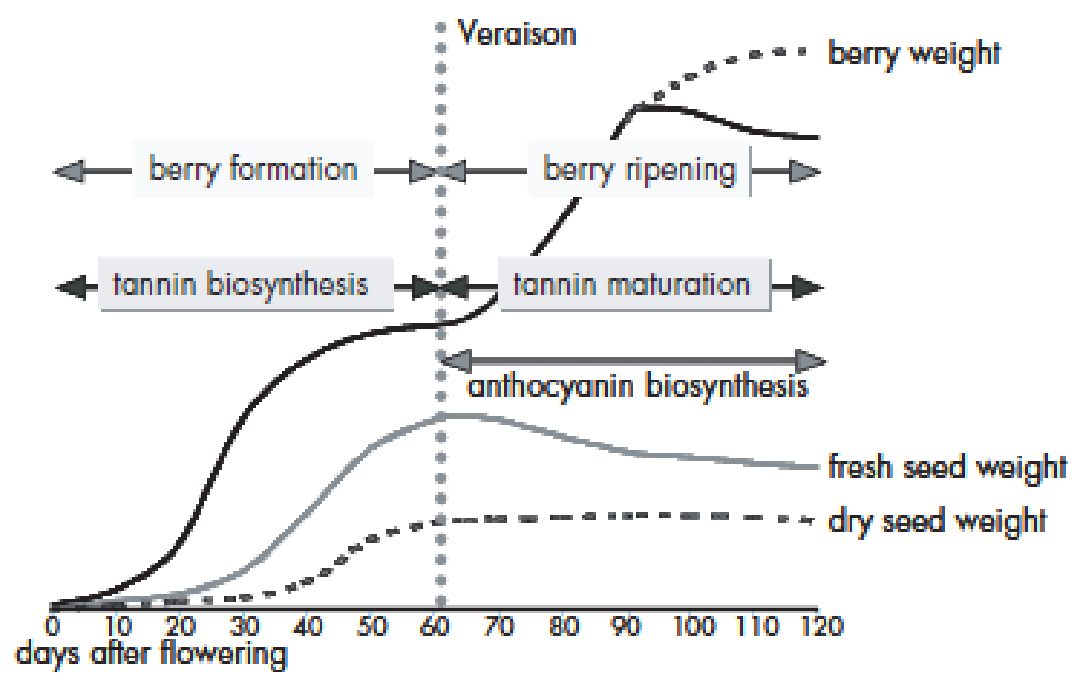

FIGURE 5

Berry formation and ripening and the biosynthesis of anthocyanin and tannin (adapted from Herderich et al., 2001).

TABLE 5

Skin thickness, total anthocyanin and extractable anthocyanin of eight Spanish cultivars (adapted from Rio Segade et al., 2008).

\begin{tabular}{|c|c|c|c|c|c|c|}
\hline \multirow[b]{2}{*}{ Cultivar } & \multicolumn{3}{|c|}{2005} & \multicolumn{3}{|c|}{2006} \\
\hline & SPsk $^{1}$ & $\begin{array}{l}\text { Total Anth } \\
(\mathrm{mg} / \mathrm{kg})^{2}\end{array}$ & $\begin{array}{c}\text { EA } \\
(\mathrm{mg} / \mathrm{kg})^{3}\end{array}$ & SPsk & $\begin{array}{c}\text { Total Anth } \\
(\mathrm{mg} / \mathrm{kg})\end{array}$ & $\begin{array}{c}\text { EA } \\
(\mathrm{mg} / \mathrm{kg})\end{array}$ \\
\hline Albarello & 213 & 425 & 380 & 270 & 432 & 301 \\
\hline Brancellao & 170 & 600 & 476 & 233 & 457 & 289 \\
\hline Ferron & 216 & 1446 & 995 & 213 & 1589 & 961 \\
\hline Gran Negro & 206 & 1062 & 730 & 188 & 1005 & 635 \\
\hline Loureira Tinta & 193 & 2524 & 1453 & 230 & 2660 & 1344 \\
\hline Merenzao & 170 & 335 & 312 & 181 & 191 & 116 \\
\hline Mouraton & 192 & 1033 & 697 & 240 & 821 & 427 \\
\hline Souson & 209 & 1732 & 1171 & 164 & 1913 & 968 \\
\hline
\end{tabular}

1. Berry skin thickness $(\mu \mathrm{m}) ; 2$. Total anthocyanin $(\mathrm{mg} / \mathrm{kg}) ; 3$. Extractable anthocyanin $(\mathrm{mg} / \mathrm{kg})$

skins. Letaief et al. (2008) tested the skin break force (Fsk, measure in Newton [N]) of three cultivars, namely Cabernet Sauvignon, Pinot noir and Nebbiolo. He found that Pinot noir required more energy to break the skin $(0.551 \mathrm{~N})$ than Cabernet Sauvignon (0.421 N), with Nebbiolo (0.398) having the softest skin (Letaief et al., 2008). Mourvedre has very thick skin and a lower extractability than Merlot, which has a thinner skin with a higher extractability (Letaief et al., 2008). In this field of research, studies can be conducted to look at the thickness of the skins of different cultivars from different regions and the subsequent extraction of anthocyanins into the wine.

The extractability of anthocyanins increases throughout berry ripening as a consequence of the pectolytic degradation of the berry cell wall (Rolle et al., 2009). Phenolic maturity thus is reached when the grape anthocyanin concentration is at its maximum (Ortega-Regules et al., 2006). Studies done by Ortega-Regules et al. (2006), Río Segade et al. (2008) and Rolle et al. (2009) have shown that the extraction of anthocyanin from the cells is a process of diffusion and that the rate of extraction is influenced by the concentration of grape anthocyanin, the composition and thickness of the berry cell walls and the processing method.

Seed maturity also plays a part of the phenolic maturity of the grapes (Romero-Cascales et al., 2005). It can be calculated by the following formula, where $\mathrm{MP} \%$ is the percentage of monopigments, TPI is the total phenols and Tskin is the total skin phenols:

$M P \%=[(T P I-T s k i n) / T P I] * 100$

Total phenols are made up of the tannins of the skins as well as the tannins of the seeds, and the values are normally between $0 \%$ and $60 \%$ (Glories, 1984a; 1984b). The MP decreases with berry ripening, therefore the higher the MP\% 
the more astringent the resulting wine will be. Thus, the $\mathrm{MP} \%$ shows the contribution of seed tannins to the wine (Romero-Cascales et al., 2005).

\section{BERRY SENSORY ASSESSMENT (BSA)}

Winter et al. (2004) compiled an assessment guide to be used in the vineyard. Many viticulturists and grape growers had their own method of assessing the potential quality or maturity of their grapes in the vineyard. These methods vary from judging the colour of the grapes, to chewing and spitting out the grapes to assess pip maturity and colour release.

In order to judge the potential quality or grape maturity of a vineyard, the grape ripening must be even. Therefore, everything starts with good agricultural practices, which related to site, variety, rootstock, clone, etc. After that, the most important prerequisite for grape quality is that the vines must be in balance. Archer and Hunter (2004) define vine balance in terms of five subgroups: i) balance between subterranean growth and growth above the surface, ii) balance between fine and thick roots, iii) balance between left and right cordons, iv) balance between shoot growth and yield, and v) balance between young and old leaves in the canopy.

According to the wine grape berry sensory assessment of Winter et al. (2004), there is a whole plethora of factors to consider. 1) Examining the softness of the berry. An unripe berry will be hard to squash and, as the berry ripens, it becomes soft and squashable. 2) Assessing the ease with which the stalk can be removed from the berry. Normally, the skin around the insertion point will be torn out in unripe berries. In ripe berries, no pulp will remain on the stalk and the "brush" will be clearly visible. 3) Examining the skin colour of red cultivars. Pink skin colour means the berry is at verraison, and the darker the skin colour, the riper the berry will be. 4) Examining pulp consistency. In unripe berries, the pulp will adhere strongly to the skin and seeds. Once the berry is ripe, no pulp will adhere to the skins and seeds and juice will be released when the berry is squashed. 5) Examining pulp sweetness, acidity and aromas. When the berry is chewed, the sweetness and acidity can be determined. The grape-specific aroma can also be determined post-nasally. 6) Examining skin disintegration. The skins of ripe grapes are easily chewed, but the skins of unripe grapes are difficult to break. 7) Examining skin tannin intensity and astringency. When eating berries with skins with low levels of phenolic compounds, the tongue will slide effortlessly across the roof of the mouth. As the grape ripens, the tongue will slide over the roof of the mouth with more and more difficulty. Astringency is noticed when there is a reaction between the grape phenolics and saliva in the mouth. The phenols bind to the proteins in the saliva and precipitate, and an astringent sensation is noticed. 8) Examining seed colour. Green, soft seeds mean that the grapes are unripe. Dark brown seeds are correlated with ripe grapes. 9) Assessing seed moisture and crushability. Green seeds are soft, but the seeds of ripe berries are hard and will crack when you bite them.

\section{WINEMAKING TECHNIQUES AND THE EXTRACTION OF ANTHOCYANIN AND TANNIN INTO WINE}

In the pre-modern era, the grape juice was left to ferment on its own. It was only after Louis Pasteur proved in 1865 that a microorganism is responsible for fermentation that modern researchers started to use active dried yeast (Pretorius et al., 1998; McGovern et al., 2005). It was also noted that the juice of red grapes is actually white and not red, as one would expect. With these observations came the next important question: what happens during fermentation that causes anthocyanins to be extracted into the wine?

During the normal fermentation of red grapes, the grapes are destemmed and crushed without breaking the pips. The juice, along with the skins, is then inoculated with an active dried yeast culture and left for at least a week to finish fermentation. Afterwards the wine is racked off the skins and the skins are pressed to obtain more of the wine that is captured between the skins. This pressed wine is stored in a wooden barrel along with the free-run wine and left for

\section{Relative adsorption (\%)}

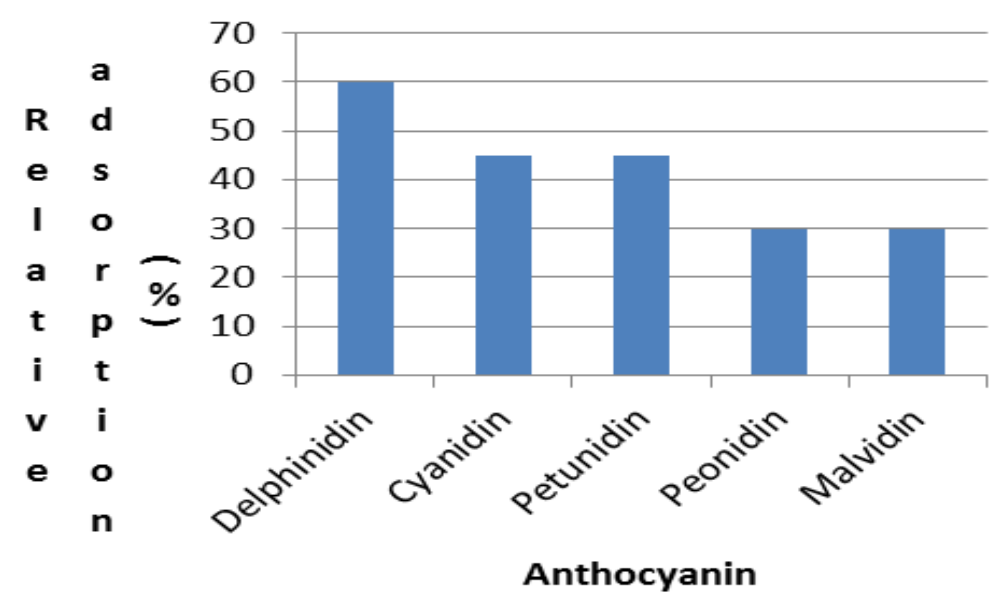

nelative adsorption (\%)

FIGURE 6

The effect of anthocyanin polarity on its adsorption by yeast lees (adapted from Vasserot et al., 1997). 


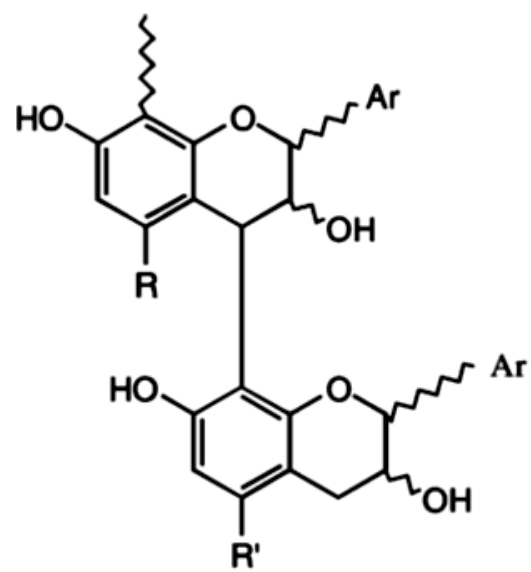<smiles>[R]c1cc(O)cc2[o+]c(C#N)c(O)cc12</smiles>

anthocyanidin<smiles>N#CCC1Oc2cc(O)cc(P)c2CC1O</smiles>

FIGURE 7

The chemistry of an acid-butanol reaction (Schofield et al., 2001)

TABLE 6

Enzymes and their potential technological effects ( $\mathrm{S}$ - sedimentation, $\mathrm{C}$ - clarification, $\mathrm{PR}$ - pressing, $\mathrm{CE}$ - colour extraction, AR - aroma release, FIL - filtration and * - indicates effect) (from Guérin et al., 2009).

\begin{tabular}{|c|c|c|c|c|c|c|}
\hline Enzyme & $\mathrm{S}$ & $\mathrm{C}$ & PR & $\mathrm{CE}$ & AR & FIL \\
\hline Pectin methyl esterase & $*$ & $*$ & $*$ & $*$ & & $*$ \\
\hline Polygalacturonase & $*$ & $*$ & $*$ & $*$ & & $*$ \\
\hline Pectin lyase & $*$ & $*$ & $*$ & $*$ & & $*$ \\
\hline Rhamnogalacturonase & $*$ & & & & $*$ & \\
\hline Galactanase & & $*$ & & & & $*$ \\
\hline Arabinase & & $*$ & & & & $*$ \\
\hline endo $(1 \rightarrow 4) \beta$-D-glucanase & & & $*$ & $*$ & & \\
\hline exo $(1 \rightarrow 4) \beta$-D-glucanase & & & $*$ & $*$ & & \\
\hline Xylanase & & & $*$ & $*$ & & \\
\hline Mannanase & & & $*$ & $*$ & & \\
\hline$\beta$-D-glucosidase & & & $*$ & $*$ & $*$ & \\
\hline$\beta$-D-galactosidase & & & $*$ & $*$ & $*$ & \\
\hline$\alpha$-L-arabinofuranosidase & & & $*$ & $*$ & $*$ & \\
\hline$\alpha$-L-rhamnosidase & & & $*$ & $*$ & $*$ & \\
\hline$\beta$-D-xylosidase & & & $*$ & $*$ & $*$ & \\
\hline$\beta$-D-apiofuranosidase & & & & & $*$ & \\
\hline$\beta$-Glucanase & & & $*$ & $*$ & & $*$ \\
\hline Protease & & $*$ & & & & $*$ \\
\hline
\end{tabular}

further maturation and malolactic fermentation.

The anthocyanins accumulate in the vacuoles or anthocyanoplasts in the epidermal cells of the grape skin. This anthocyanin can easily be released from the cells when these cell walls are mechanically broken. Tannins form complexes with cell wall components and are therefore more difficult to release, as these complexes must first be broken. Herderich et al. (2001) found that only about $10 \%$ to $24 \%$ of grape tannins could be detected in the wine and that the concentration of these tannins was related to the winemaking practices. Adams and Scholz (2007) found that about 60\% of seed tannins and about $40 \%$ of skin tannins are extracted 
during normal winemaking practices. The distribution of proanthocyanidins in the grapevine and of which is roughly extracted in the wine per plant part is roughly as follows: $66 \%$ in the seeds, $45 \%$ in the stems, $28 \%$ in the leaves and only about $26 \%$ in the skins. If the leaves and stems are crushed and used for the winemaking process, too much tannin will be extracted, which will have a negative effect on the mouthfeel of the wine.

\section{Cold soaking}

Cold soaking/maceration is known as the pre-fermentation skin contact time. During the crushing of the grapes, the vacuoles of the skin cells are broken and the anthocyanins can seep out. The absence of alcohol at this time allows the formation of higher molecular-weight pigmented phenolic species, which will enhance colour stability (McMahon et al., 1999).

Cold soaking can be done at different temperatures and for different lengths of time, as a number of studies have shown. Gómez-Plaza et al. (2000) used Monastrell grapes that were cooled down to $10^{\circ} \mathrm{C}$ for five days and in 2001 tested three different maceration times (four, five and 10 days). In both studies, Gómez-Plaza et al. (2000; 2001) found that low maceration temperature $\left(10^{\circ} \mathrm{C}\right)$ and longer maceration time (10 days) had a positive influence on the anthocyanin concentration, chromatic characteristics and hydroxyl cinnamic acid derivatives of the wines. After storage for twelve months, the wines made with the longer maceration time (10 days) kept their colour density and phenolic content for longer than those with the shorter maceration time (four days) (Gómez-Plaza et al., 2000). Longer skin contact time may lead to greater polymerisation of pigments and higher concentrations of procyanidins , and therefore to greater colour stability in the early stages of red wines (Gómez-Plaza et al., 2001). Álvarez et al. (2009) used Tempranillo that was cooled to between $5^{\circ} \mathrm{C}$ and $8^{\circ} \mathrm{C}$ for four days, and Gil-Muñoz et al. (2009) used Cabernet Sauvignon and Shiraz that was cooled down to $10^{\circ} \mathrm{C}$ for seven days. They also found that the low maceration temperature gave a higher concentration of anthocyanins and total phenols.

In a study done by McMahon et al. (1999) on Pinot noir, it was found that cold soaking at $4^{\circ} \mathrm{C}$ gave darker, less bitter wines, while at $10^{\circ} \mathrm{C}$ the Pinot noir had less colour and more woody-tobacco aroma, with an increase in bitterness. The majority of anthocyanin is extracted after the fermentation of the first $10^{\circ} \mathrm{B}$ (McMahon et al., 1999), although anthocyanin ionisation increases with maceration time (Gómez-Plaza et al., 2001). Tannins continue to be extracted throughout the fermentation process, and pressing of the skins prior to dryness enhances fruity character, limits astringency and decreases the total phenol concentration (McMahon et al., 1999). Although a decrease in tannin concentration may limit astringency, a high concentration of tannin may stabilise anthocyanin (more stable colour), but it can also lead to excessive astringency in wines. Reactions involving the stabilisation of anthocyanin are the formation of co-pigmentation (Boulton, 2001), acetaldehyde-mediated condensation (Timberlake \& Bridle, 1976; Somers \& Evans, 1986), and the formation of polymers with tannins.

Parenti et al. (2004) tested two different cryogens, solid state $\mathrm{CO}_{2}$ and liquid $\mathrm{N}_{2}$, on Sangiovese. The cryogens were used to cool the grapes down to $-5^{\circ} \mathrm{C}, 0^{\circ} \mathrm{C}$ and $5^{\circ} \mathrm{C}$ for two days. They found that a decrease in cold maceration temperature led to an increase in extraction of anthocyanins and wine quality, up to a point where any further decrease in temperature had no effect on any further extraction of anthocyanins.

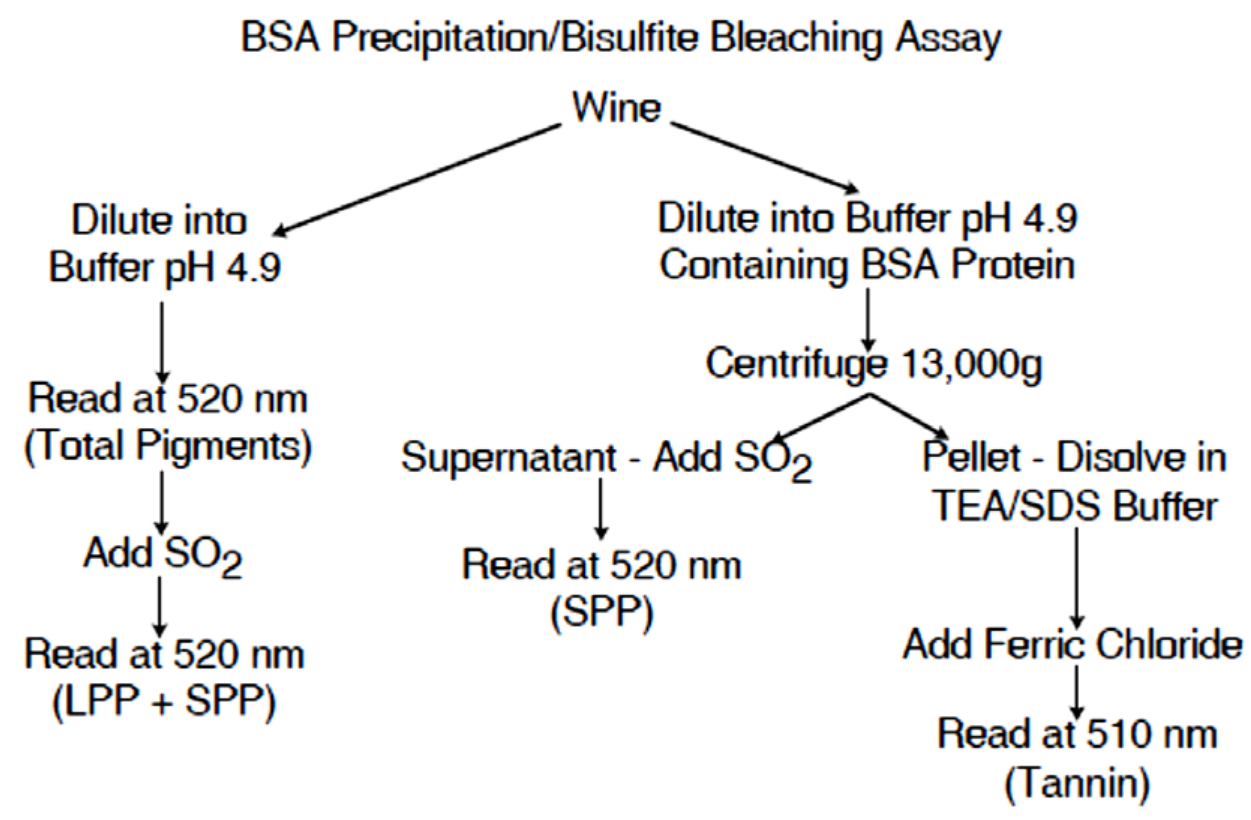

FIGURE 8

Schematic representation of the determination of tannin and polymeric pigments in grape extracts and wine by protein precipitation combined with bisulphate bleaching (Harbertson et al., 2003). 


\section{Carbonic maceration}

Clusters of whole berries are held in a carbon dioxide atmosphere and partial fermentation occurs because of the activity of glycolytic enzymes that are present in the grapes (Sacchi et al., 2005). After a specific period of time, typically one to two weeks, the grapes are pressed and the juice is inoculated with wine yeast to complete the fermentation (Sacchi et al., 2005). This method is normally used to produce lighter, fruity wines that are meant to be consumed young (Sacchi et al., 2005).

Studies done in Spain on Shiraz (Gómez-Míguez \& Heredia, 2004), Tempranillo and a Tempranillo/Viura mix (Etaio et al., 2008) have shown that carbonic maceration produces wines that have a low anthocyanin concentration, low total phenols, low tree fruit and liquorice flavours, as well as low glycerol, titratable acids and colour density, but higher concentrations of red berry aromas.

Most studies have shown that wines made by the carbonic maceration method have low amounts of colour and total phenols (Gómez-Míguez \& Heredia, 2004; Etaio et al., 2008), although some studies show otherwise.

\section{Enzymes}

An important factor in the extraction of proanthocyanidins and anthocyanins is the use of enzymes. There are different enzymes in the market for the winemaker to choose from. Every enzyme preparation has a different composition that will have a different mode of working in the juice or wine.

Arnous and Meyer (2010) found that the phenolic composition of grape skins is released by the random liberation of phenols from the grape skin cell wall matrix in response to the progressive enzyme-catalysed degradation of the cell wall polysaccharides. Flavonols and hydrobenzoic acids are integrated into the skin cell wall polysaccharide via hydrophobic interactions and/or hydrogen bonds (Arnous \& Meyer, 2010). Tannins form complexes with cell wall components and therefore are more difficult to release than anthocyanins. With the help of the enzyme components of hemicellulase and cellulase, the bonds between the tannin complexes are broken and the tannins can be released (Bautista-Ortín et al., 2005). It has also been found that the flavonol rutin was changed into aglycone quercetin as a result of a two-step deglycosylation of rutin (Arnous \& Meyer, 2010).

The enzymes for anthocyanin extractability appear to be affected by the density of the cell wall polysaccharide matrix, therefore the cell wall acts as a protective shield for the extraction of the anthocyanins. The anthocyanins therefore are released by cell wall rupturing and not totally by enzymatic activity (Arnous \& Meyer, 2010). An extended enzymatic treatment affects anthocyanin negatively, as there is a loss of total anthocyanins caused by temperature, while the loss of acylated anthocyanin might be from the formation of hydrocinnamic acids (Arnous \& Meyer, 2010).

According to Revilla and González-San José (2003) there basically are two large groups of commercially prepared enzymes: the clarifying enzymes and the colour extractors. The clarifying enzymes are normally pectolytic enzymes that break down the pectin bond and therefore help to reduce the turbidity of the juice. The colour extractors or maceration enzymes consist of a cocktail of enzymes such as pectin lyase (PL), pectin methyl esterase (PE), polygalacturonase (PG), hemicellulase, cellulose and protease, with glucosidase activity (Revilla \& González-San José, 2003). These maceration enzymes not only help with the release of anthocyanins, but also help with the extraction of tannins (Revilla \& González-San José 2003; Arnous \& Meyer, 2010).

Commercial enzymes are preparations of a mixture of different enzymes, each with its own mode of working. Guérin et al. (2009) analysed 41 commercially available enzyme preparations to evaluate their mode of working and classified them for their technological effects of sedimentation, clarification, pressing, colour extraction, aroma release and filtration. Table 6 shows the potential technological effects of these enzymatic activities.

Wines with higher colour and tannin concentrations tend to form more stable anthocyanins as the wine matures. There was also an increase in the aroma of the wine as well as a better mouth feel (Bautista-Ortín et al., 2005; Revilla \& González-San José 2003).

\section{Yeast}

It is well known that yeast cell walls have an adsorption effect and that these cell walls may help the winemaker in removing some off-odours as well as proteins. Another effect of yeast cell walls is that they can remove a portion of anthocyanins by adsorption. In a study done by Vasserot et al. (1997), they found that the process of adsorption of anthocyanins by yeast lees appears to be limited by the reaching of partition equilibrium between a fraction of anthocyanin that would be free in solution and anthocyanin that would be adsorbed on the yeast cell walls. ScudamoreSmith et al. (1990) also found there was a rapid increase in colour density during fermentation, but that there was a sharp decrease at the end of fermentation due to adsorption of anthocyanin to yeast lees.

The different anthocyanins have different degrees of polarity and therefore will adsorb differently on yeast lees, as can be seen in Fig. 6. Delphinidin, with the highest polarity, will be the most adsorbed, while malvidin, with the lowest polarity, will be less adsorbed.

There are different factors that would affect the adsorption of anthocyanin on yeast lees, namely

i) Temperature - Lower temperature affects the adsorption capacity better than higher temperature.

ii) Ethanol - The amount of anthocyanin adsorbed decreases with an increase in ethanol concentration.

iii) $\mathrm{SO}_{2}-\mathrm{As}$ the $\mathrm{SO}_{2}$ concentration increases, the amount of anthocyanin adsorbed decreases. $\mathrm{SO}_{2}$ also forms a reaction between the flavylium cation $\left(\mathrm{A}^{+}\right)$to form a colourless chromen-2-sulfonic acid $\left(\mathrm{AHSO}_{3}\right)$.

iv) $\mathrm{pH}-\mathrm{As}$ the $\mathrm{pH}$ of the wine increases, the amount of anthocyanin adsorbed decreases. Because of an increase in $\mathrm{pH}$, the balance of the flavylium cation shifts to the uncharged carbinol pseudobase (Vasserot et al., 1997).

\section{Thermovinification}

Thermovinification is a process in which whole or crushed grapes are heated to a temperature between $60^{\circ} \mathrm{C}$ to $80^{\circ} \mathrm{C}$ for 
20 to 30 minutes to promote the diffusion of phenolic and colour compounds from the grape skins (Ribereau-Gayon et al., 2000). The heating damaged the hypodermal cell membranes and the anthocyanins are released (Lowe et al., 1976; Sacchi et al., 2005). The coloured juice can now be cooled and pressed or pressed and cooled to fermentation temperature, and the juice is handled as for normal white juice (Lowe et al., 1976).

Different studies on thermovinification have found that the concentration of anthocyanins increases (Lowe et al., 1976; Sacchi et al., 2005; Baiano et al., 2009), while the concentration of the flavonoids remains low (Sacchi et al., 2005; Baiano et al., 2009). In one study, Wagener (1981) found that the wine made from systems (Imeca and Sernagiotto plants) in which they used a destemmer and final press was very dark in colour and astringent. It was also found that the heating of the must denatured polyphenol oxidase (PPO), thus preventing browning of the wine (Sacchi et al., 2005).

\section{Extended maceration}

The rationale behind maceration is that, with cold soaking, more colour will be extracted from the grape skins and, with extended maceration, more phenols will be extracted, which will help to stabilise the wine colour and tannin structure. A study was done on the consequences of extended maceration on red wine colour and phenolics by the University of Adelaide (Joscelyne \& Ford, 2008). They found that extended maceration resulted in a lower colour intensity but higher hue (browner colour) and total phenols than the other treatments. This confirmed a study done by Zimmer et al. (2000), who they tested Cabernet Sauvignon from different Californian regions. An extended maceration of twenty days after fermentation showed that the proanthocyanidins increased significantly - from $17 \%$ to $41 \%$ (Zimmer et al., 2002). There was a difference in the phenolic composition of the Pinot noir wine from one week to three weeks of extended maceration. The extra two weeks altered the phenolic composition of the Pinot noir significantly (Joscelyne \& Ford, 2008).

\section{ANTHOCYANINS AND THE DIFFERENT METHODS OF ANTHOCYANIN ANALYSIS}

Tannins are also important as they contribute to organoleptic characteristics such as astringency (Gawel, 1998; Monagas et al., 2005) and bitterness (Monagas et al., 2005), as well as to colour stability (Monagas et al., 2005), maturation potential (Lorenzo et al., 2005) and health benefits (Corder, 2007). It is for these reasons that the quantification of tannins is very important to the winemaker and viticulturist. For the winemaker to produce a good red wine with good maturation potential, the tannin and anthocyanin contents of that grapes must be known.

There are a large number of different methods to analyse tannins or total phenols in grapes and wine. This section will touch on the different methods. At the end of this section, the two most popular tannin methods will be discussed.

\section{DETERMINATION OF TOTAL POLYPHENOLS AND} TANNINS

Total polyphenols is a term used to describe compounds that have a benzene ring with one or several hydroxyl groups $(-\mathrm{OH})$ attached to them (Schofield et al., 2001). These polyphenols are further divided into non-flavonoid (cinnamic acids, caffeic acids, etc.) and flavonoids (flavanols, flavonols, flavan-3-ols, etc.). The non-flavonoid compounds are found mainly in the pulp of the grape berry, and the flavonoid compounds are found in the skins (proanthocyanidins) and the seeds (procyanidins) of the grape berry (Schofield et al., 2001).

There are many publications available on tannin analyses (Folin \& Ciocalteu, 1927; Hagerman \& Butler, 1978; Butler et al., 1982; Makkar, 1989; Souquet et al., 1996; Giner-Chavez et al., 1997; Price \& Butler, 1997; Sun et al., 1998; Schofield et al., 2001; Hagerman, 2002; Harbertson et al., 2003; De Beer et al., 2004; Moris \& Silber, 2006; Sarneckis et al., 2006; Seddon \& Downey, 2008). However, not all of these analyses are applicable to grape tannins. Based on the available literature, the methods for the analysis of grape tannins can be divided into four basic groups, namely colorimetric methods, gravimetric methods, precipitation methods and HPLC (high performance liquid chromatography).

\section{COLORIMETRIC METHODS}

Colorimetric methods have their basis in the colouring of the solution with either acid-butanol or a dye like Prussian blue (Price \& Butler, 1997). Condensed tannins or proanthocyanidins are mainly found in the skins of grapes (Monagas et al., 2005). They are called proanthocyanidins because they break down to coloured cyanidins and delphinidins in an acid medium (Porter et al., 1986; Monagas et al., 2005).

\section{Acid-butanol assay}

In the acid-butanol assay, proanthocyanidins can be quantified (Makkar, 1989). The interflavan links of the condensed tannins are broken under acidic conditions and the corresponding anthocyanidins are forced into the colour form, which can be determined at A550 with a spectrophotometer (Fig. 7). There are a number of limitations to this assay, as summarised in Schofield et al. (2001), and these must be taken into consideration.

First, the amount of water in the reaction medium is critical to colour formation and the quantitative determination of the proanthocyanidins. Second, the ease with which the interflavan bonds cleave differs. The $4 \rightarrow 6$ bonds are more resistant to this cleavage than the $4 \rightarrow 8$ bonds. Third, the number of phenolic groups in rings $\mathrm{A}$ and $\mathrm{B}$ affect the wavelength of the absorbance maximum. Fourth, the colour yield is not always linear to the amount of tannin input. Fifth, the presence of transitional metal ions in the assay medium is also important. Finally, the ratio of acid-butanol:sample medium in the reaction mixture is important (Schofield et al., 2001). 


\section{Thioacidolysis}

Another form of acid cleavage reaction is thioacidolysis (thiolysis) or phloroglucinol. The mean degree of polymerisation is determined with this method, as well as (+)-catechin, (-)-epicatechin and (-)-epicatechin-3-Ogallate and their corresponding benzylthioethers (Souquet et al., 1996). In this method, condensed tannin is heated with toluene- $\alpha$-thiol (benzyl mercaptan), which releases the terminal unit as a flavan-3-ol, while the extension units are released as toluene- $\alpha$-thiol derivatives. The disadvantage of the use of toluene- $\alpha$-thiol is the strong mercaptan aroma, therefore a more popular reagent to use is phloroglucinol. The principles for phloroglucinol are the same as for thioacidolysis. These methods are used in conjunction with reverse-phase HPLC to determine the mean degree of polymerisation.

\section{Vanillin assay}

The vanillin assay is used to determine the quantitation of condensed tannin, as well as to determine the degree of polymerisation $(\mathrm{mDP})$ of proanthocyanidins. The vanillin assay depends on the reaction between vanillin and the condensed tannin to achieve a coloured complex that can be determined at A500. Because of the concentration of flavan-3-ol end groups, the chromophore concentration increases (Butler et al., 1982). This assay is insensitive to the differences between procyanidins and prodelphinidins, and therefore catechin is used as the standard, although it can lead to an overestimation of tannin (Butler et al., 1982).

The above is a relatively easy assay to use, and also relatively quick, as it takes about 30 minutes to complete, but there are a number of critical factors that have to be borne in mind. Firstly, the type of solvent used must be considered, as at the same normality, $\mathrm{HCl}$ contains more water than $\mathrm{H}_{2} \mathrm{SO}_{4}$ and therefore gives low reproducibility (Sun et al., 1998). The reaction time must be kept at 15 minutes, and the temperature must be between $25^{\circ} \mathrm{C}$ and $30^{\circ} \mathrm{C}$. The vanillin concentration must be between 10 and $12 \mathrm{~g} / \mathrm{L}$. Finally, the type of reference standard used must be taken into account, because purified oligomeric proanthocyanidins express the proanthocyanidin content more correctly than $(+)$ - catechin (Sun et al., 1998; Hagerman, 2002).

\section{Folin-Ciocalteu method}

The Folin-Denis method was first described by Folin and Denis (1912), but was later modified to the Folin-Ciocalteu method by Otto Folin and Vintila Ciocalteu (1927). Total phenols of wine are determined with the Folin-Ciocalteu assay. This method is based on the reducing power of the phenol hydroxyl group. This method is not very specific and can detect all the phenols (Makkar, 1989) to varying degrees of sensitivity (Sun et al., 1998). Normally, $1 \mathrm{~mL}$ of wine is put in a $100 \mathrm{~mL}$ Erlenmeyer flask with $60 \mathrm{~mL}$ of distilled water and $5 \mathrm{~mL}$ of Folin-Ciocaltue reagents. After a waiting period of between 30 seconds to 480 seconds, $15 \mathrm{~mL}$ of sodium bicarbonate is mixed into the Erlenmeyer flask and then topped up to its mark. This is an easy-to-do assay, but it has a long waiting period of about two hours. A standard curve must be set up using gallic acid as the reference standard. Singleton et al. (1999) found that it was difficult to correlate results from Folin-Ciocalteu assays with HPLC measurements due to the diverse group that constitutes the total phenolics in wine.

\section{Prussian blue assay}

The Prussian blue assay is a very simple and quick method with low interference by non-phenolic compounds. This assay was first described by Price and Butler (1977) and is a popular method for the quantification of total phenols (Makkar, 1989). Although this is an easy method, it has its shortcomings. There is the formation of a precipitate after a short incubation period and an increase in colour density over a time (Schofield et al., 2001). A summary of the oxidationreduction reaction looks as follows:

Polyphenol $+2 \mathrm{Fe}(\mathrm{CN})_{6}^{3-}$ (ferricyanide ion) $\rightarrow$ oxidized polyphenol $+2 \mathrm{Fe}(\mathrm{CN})_{6}^{4-}$ (ferrocyanide ion) then

$3 \mathrm{Fe}(\mathrm{CN})_{6}{ }^{4-}$ (ferrocyanide ion) $+4 \mathrm{Fe}^{3+} \rightarrow \mathrm{Fe}_{4}\left[\mathrm{Fe}(\mathrm{CN})_{6}\right]_{3}$ (Prussian blue)

Moris and Silber (2006) developed a method in which they use alkaline Coomassie brilliant blue combined with bovine serum albumin (CBB-BSA) to bind to grape tannin. The resulting coloured form is read at an absorbance of A602. This method works so well that they developed a hand-held device that can be used in vineyards to determine the tannin content (Moris \& Silber, 2006).

\section{GRAVIMETRIC METHOD}

The gravimetric method is very complex and consists of a number of steps. However, it does not require a standard for external calibration. This method uses the trivalent cation of a rare earth metal, ytterbium $\left(\mathrm{Yb}^{3+}\right)$, to form a complex with the tannin and to precipitate it. This precipitate (ytterbium oxide-tannin) is then ashed and weighed. The precipitate is then compared to an internal and external standard. The external standard consists of cyanidins, delphinidin and purified Quebracho tannin. The internal standard consists of condensed tannins from the plant species that were isolated with either Sephadex LH-20 or trivalent ytterbium (GinerChavez et al., 1997). Fig. 8 shows the different steps that are used in this method for the determination of total phenols.

Herderich and Smith (2005) found that the ytterbium method is not suitable for the grape tannin analysis of a $50 \%$ ethanol solution of grape extract. Giner-Chavez et al. (1997) found that, when external standards were used, the tannin content was over- or underestimated; however, good results were obtained when they used the type of tannin of the plant to be analysed.

\section{PRECIPITATION METHODS}

According to the definition of White (1957), tannin is a compound that has the ability to precipitate proteins. It is this unique ability of tannin that Hagerman and Butler (1978) used to develop a method to analyse condensed tannins.

\section{Bovine serum albumin (BSA) assay}

The first of these precipitation methods is the BSA assay, which was developed in California by Hagerman and Butler (1978). The method involves the formation of protein-tannin 
complexes (Hagerman \& Butler, 1978). Tannin, in a mildly acidic medium, has a negative charge. Protein, on the other hand, has a positive charge. These opposite charges attract each other, forming a complex. This complex precipitates in a pellet form after the sample has been centrifuged. Hagerman and Butler (1978) decided on bovine serum albumin (BSA) as their protein of choice after experimenting with different protein sources. The BSA is mixed with an acetate buffer before the addition to the wine sample. The mixture is left for 15 minutes at room temperature before it is centrifuged for 15 minutes at $5000 \mathrm{~g}$ (Hagerman \& Butler, 1978), or for 5 minutes at $13000 \mathrm{~g}$ (Harbertson et al., 2003). The pellet that is formed is re-dissolved with a $1 \%$ sodium dodecyl sulphate (SDS) and 5\% triethanolamine (TEA) buffer. In the original method developed by Hagerman and Butler (1978), they used 1\% SDS, but in the study done by Harbertson et al. (2003) they used 5\% of SDS. After another 10 minutes at room temperature, the mixture is measured in a spectrophotometer at A510 as tannin background ( $\left.\mathrm{T}_{\text {background }}\right)$. The mixture is then mixed with ferric chloride and read at A510 as tannin final $\left(\mathrm{T}_{\text {final }}\right)$ after standing for 10 minutes at room temperature, using the following formula:

$\operatorname{Tan}=\left(\mathrm{T}_{\text {final }}-\mathrm{T}_{\text {noise }}\right)-\left(\mathrm{T}_{\text {background }} * 0.875\right)$

For tannin noise $\left(\mathrm{T}_{\text {noise }}\right)$, buffer $\mathrm{C}$ (SDS and TEA) and ferric chloride are mixed and measured at A510 on the spectrophotometer. The answer to the abovementioned equation is put into a standard curve to get to the final tannin concentration of $(+)$-catechin equivalents $(\mathrm{CE})$ in $\mathrm{mg} / \mathrm{L}$. With the addition of ferric chloride the mixture turns blue. This method is an indirect method for tannin analysis, and the result is actually ferric-binding tannin. Harbertson et al. (2003) modified the BSA assay by combining it with a bisulphate bleaching step. This is done in three different steps and the result is the determination of monomeric pigments (MP), small polymeric pigments (SPP) and large polymeric pigments (LPP). With the first step one can differentiate between monomeric anthocyanins from the polymeric pigments. With the other two steps one can differentiate between the small polymeric pigments (SPP), which do not precipitate, and the large polymeric pigments (LPP), which do precipitate.

\section{Methyl cellulose precipitation (MCP) method}

The second precipitation method is called the methyl cellulose precipitation assay (MCPT), which was developed in Australia (Sarneckis et al., 2006). According to this method, the polysaccharide methyl cellulose, which has also a positive charge, will bind to tannin. A pellet is formed after the mixture has been centrifuged. Two microfuge tubes are prepared - one with the methyl cellulose and one without. Both of the microfuges are measured in a spectrophotometer at an absorbance of A280 (UV spectrum) in a quartz cuvette. The one value is subtracted from the other. The final value is put into the standard curve to get to the final tannin concentration, which is in (-)-epicatechin equivalents (EE $\mathrm{mg} / \mathrm{L})$.

\section{HIGH PERFORMANCE LIQUID CHROMATOGRAPHY} (HPLC)

HPLC is a very accurate method for the identification and quantification of monomeric to trimeric proanthocyanidins, although it is difficult to differentiate between the polymeric tannins and complex compounds found in wine. This can be done by using two variations of the HPLC method, namely normal-phase and reverse-phase HPLC.

Normal-phase HPLC uses polar packing with a nonpolar mobile phase, which means that polar compounds (hydrophilic compounds) will elute first, while the non-polar compounds (hydrophobic compounds) will elute last. In a study done by De Beer et al. (2004), the proanthocyanidins, which were detected at $280 \mathrm{~nm}$, were divided into three groups: monomers, low molecular-weight proanthocyanidins and high molecular-weight proanthocyanidins.

Reverse-phase HPLC uses non-polar packing with a polar mobile phase. This means that the non-polar compounds (hydrophobic compounds) will elute first, while the polar compounds (hydrophilic compounds) will elute last. In the same study by De Beer et al. (2004), the compounds that were identified were benzoic acids, hydrocinnamates, flavan3-ols, flavonols and anthocyanins. De Beer et al. (2004) found that (-)- epicatechin co-elutes with anthocyanins and could therefore not be quantified successfully.

According to Sarneckis et al. (2006) there is a very good correlation between the tannin measurements using the MCP assay and those using reverse-phase HPLC. Of the 121 Australian red wines that were analysed, the correlation was $\mathrm{R}^{2}=0.74$, and for the 54 grape extracts it was $\mathrm{R} 2=0.79$. Seddon and Downey (2008), however, found the opposite, namely that there is poor correlation between the MCP and BSA assays $\left(\mathrm{R}^{2}=0.41\right)$ and that the correlation between protein precipitation and the HPLC-phloroglucinolysis is very good $\left(\mathrm{R}^{2}=0.91\right)$, while the correlation between the methyl cellulose and HPLC-phloroglucinolysis is very poor $\left(\mathrm{R}^{2}=0.25\right)$.

\section{ANTHOCYANINS AND THE DIFFERENT METHODS OF ANTHOCYANIN ANALYSIS}

Anthocyanin is a flavylium cation with a positive charge. When a glucose molecule is glycosylated to this flavylium cation, an anthocyanin is formed. Anthocyanins are found mainly in the vacuoles of the epidermal cells.

There are a few methods to determine the anthocyanin content of grapes, namely the Iland method, HPLC, colour density, hue, Boulton and Levengood, Somers and Evens, and Ribéreau-Gayon and Stonestreet.

\section{Iland method}

Iland et al. (2000) devised a method to determine the total anthocyanin content of grapes. The skin of red and black grapes is coloured various shades of red and/or bluish black due to the presence of red-coloured pigments, mainly anthocyanins. The anthocyanins are extracted from the skins during fermentation. They, along with oligomeric and polymeric compounds, give red wine its colour. 
A measure of the concentration of red-coloured pigments in berries can provide an indication of the potential colour of wine made from those grapes. The relationship between the measure of grape colour and wine colour is based on the assumption that: i) all the anthocyanins are extracted from the skins, ii) there is no loss of anthocyanins due to precipitation or polymer formation, and iii) all wines are made in a similar manner.

The method is based on the extraction, with ethanol, of the pigments from a known weight of macerated whole grapes. One hundred berries are weighed and homogenised in a homogeniser. A portion of $2 \mathrm{mg}$ of the homogenised grapes is extracted in an ethanol solution $(\mathrm{pH} \mathrm{2.0)}$. This extract is mixed in a rotator $(100 \mathrm{rpm})$ for an hour before it is centrifuged. The extract is then diluted with $1 \mathrm{M} \mathrm{HCl}$ and left for three hours, after which the absorbance of the solution is measured on a spectrophotometer at $520 \mathrm{~nm}$. The calculation of red pigments is based on the use of the extinction coefficient of malvidin-3-glucoside, and the result is expressed as equivalents of this anthocyanin.

$\mathrm{Mg}$ of anthocyanin/berry $=\left(A 520_{\mathrm{HCl}} / 500\right) \times 11 \times(21 \mathrm{~mL} / 100)$ $x$ (weight of 100 berries $(g) /$ weight of homogenate $(g)) x(1$ 000/50)

$\mathrm{Mg}$ of anthocyanin/berry $=\left(\mathrm{A520}_{\mathrm{HC}} / 500\right) \times 11 \times(21 \mathrm{~mL} / 100)$ $x$ (weight of 100 berries $(\mathrm{g}) /$ weight of homogenate $(\mathrm{g})$ ) $x$ (1000/ weight of homogenate $(\mathrm{g})$ )

Studies have shown that the measure of grape colour can act as a predictor of wine colour. In practice, the measure of grape colour generally can predict if a wine will be lightly, moderately or intensely red coloured. In some cases it can also provide an indication of the flavour intensity of the wine and of wine quality, particularly when grapes and wines produced from within a similar climatic region are compared (Iland et al., 2000).

\section{Colour density}

Colour density is probably the easiest and quickest method to obtain an indication of the anthocyanin content. This method gives the value in absorbance units (AU). The traditional method (Glories, 1984a; 1984b) to determine colour intensity is calculating the sum of yellow/brown, red and purple hue absorbance, as shown in Eq. 4.

Colour density $=A 420+A 520+A 620$

Iland (2000) divided wines into three categories based on their colour density:

$$
\begin{array}{ll}
\text { - } & \mathrm{AU}<6=\text { light wines } \\
\text { - } & \mathrm{AU} 6-10=\text { medium wines } \\
& \mathrm{AU}>10=\text { heavy wines }
\end{array}
$$

Therefore, colour density measures how much colour there is in a wine (Harbertson \& Spayd, 2006). Low colour densities of a wine compared to a wine with high colour density from the same region can be explained by the pigment composition and state of pigment equilibrium of that wine (Somers \& Evans, 1974). Factors that can affect colour density are the $\mathrm{pH}$ and the sulphur dioxide $\left(\mathrm{SO}_{2}\right)$ content of the wine (Somers \& Evans, 1974). It was found (Somers \& Evans, 1974) that $20 \%$ to $25 \%$ of the total anthocyanins are in the coloured flavylium form at $\mathrm{pH} 3.4$ to 3.6. Sulphur dioxide $\left(\mathrm{SO}_{2}\right)$ in wine exists in the bisulphate $\left(\mathrm{HSO}_{3}^{-}\right.$) form. This $\mathrm{HSO}_{3}^{-}$has a decolouring effect on the wine, as the $\mathrm{HSO}_{3}$ - binds to the flavylium ion to form a colourless flavene sulphonate (Somers \& Evans, 1974). As the anthocyanins polymerise into polymeric pigments they become less sensitive to $\mathrm{SO}_{2}$ and $\mathrm{pH}$ changes (Somers \& Evans, 1974).

To determine the $\mathrm{SO}_{2}$-resistant anthocyanins or anthocyanin colour, some of the wine sample is bleached with a $20 \%$ sodium metabisulphate solution. The difference between the bleached sample and the wine colour gives the anthocyanin colour (Somers \& Evans, 1974).

Anthocyanin colour $=A 520-A 520_{S O 2}$

Polymeric pigment colour $=A 520_{S O 2}$

The tone or hue of a wine is used to monitor wine ageing (Harbertson \& Spayd, 2006). This is calculated as the ratio between A420 and A520.

Hue/tone $=[$ A420/A520]

In young wines, these values are between 0.5 and 0.7 and reach values of 1.2 to 1.3 in aged wines. This is a very useful way to look at the ageing of red wine - as a shift from red to brick red (Harbertson \& Spayd, 2006).

\section{Boulton and Levengood assay (co-pigment assay)}

A factor that traditional analytical methods do not consider is the tendency of young red wines to form self-associations or co-pigmentations due to the molecular associations between anthocyanins and other organic molecules in the solution. It is apparent that co-pigmentation accounts for between $30 \%$ and $50 \%$ of the colour of young wines. It is these associations that cause the anthocyanins to exhibit a more intense colour than expected (Boulton, 2001).

Levengood and Boulton (2004) used spectrophotometric measures to determine the co-pigmentation of Cabernet Sauvignon. This is a time-consuming method that can take as long as 75 minutes to 90 minutes, as it involves a number of steps. First of all, the $\mathrm{pH}$ of the wine must be adjusted to $\mathrm{pH} 3.6$ and the wine filtered through a $0.45 \mu \mathrm{m}$ filter. Acetaldehyde is put in an aliquot with the wine and the colour is determined at $520 \mathrm{~nm}$ after a 45 -minute wait. The wine is then diluted in another aliquot and the colour is also determined at $520 \mathrm{~nm}$ after 10 minutes. $\mathrm{SO}_{2}$ solution is added in a third aliquot and the colour is also determined after 10 minutes at $520 \mathrm{~nm}$. The following formula is then used to determine the colour due to co-pigmentation.

Colour due to co-pigmentation $=A_{\text {acet }}-A_{\text {dilute }}$

Levengood and Boulton (2004) found that the mean absorbance unit (AU) for colour due to co-pigmentation falls in the range of 1.81 to 5.67 (mean of 3.34), while the AU for anthocyanins is in a range of 1.20 to 3.23 (mean of 2.01).

In a comparison study done by Versari et al. (2008), an experiment was done to determine the correlation between Boulton's co-pigmentation method and reverse-phase 
HPLC. The analysis of the phenolic compounds was done using a reverse-phase (RP-C18) column. Versari et al. (2008) found an overall good correlation with total colour (R2 = $0.8999)$ and free anthocyanins $(\mathrm{R} 2=0.9159)$, and a very good correlation with co-pigmentation $(\mathrm{R} 2=0.9464)$.

\section{Somers and Evans assay}

This is a long analytical method. The anthocyanins are all forced into the red flavylium form by mixing the wine sample with $1 \mathrm{~N} \mathrm{HCl}$. The mixture is left for three to four hours, after which the total anthocyanin content is determined at $520 \mathrm{~nm}$. Sodium metabisulphate is mixed with wine and also determined at $520 \mathrm{~nm}$. The anthocyanin concentration is then expressed as mg/L (Rivas-Gonzalo et al., 1992).

$$
\begin{aligned}
& \text { Anthocyanin concentration }(\mathrm{mg} / \mathrm{L})=19.6^{*}\left(\mathrm{A520} \mathrm{HCl}_{-}\right. \\
& \mathrm{A52O}_{\mathrm{SO}_{2}} \text { ) }
\end{aligned}
$$

\section{Ribéreau-Gayon and Stonestreet assay}

This is a faster method than Somers and Evans's method, as it take about 15 minutes. One $\mathrm{mL}$ of wine is mixed with $1 \mathrm{~mL}$ of ethanol/ $\mathrm{HCl}$ solution $(96 \%$ ethanol $+0.1 \mathrm{v} / \mathrm{v} \mathrm{HCl})$ and $20 \mathrm{~mL}$ of an aqueous solution. Ten $\mathrm{mL}$ of the above mixture is added to two test tubes. In one test tube, $4 \mathrm{~mL}$ of water is added, and in the other test tube $4 \mathrm{~mL}$ of $\mathrm{NaHSO}_{3}$. After 15 minutes the samples from both test tubes are measured at $520 \mathrm{~nm}$ (Rivas-Gonzalo et al., 1992).

Anthocyanin concentration $(\mathrm{mg} / \mathrm{L})=615^{*}(A 1-A 2)$

A study done by Rivas-Gonzalo et al. (1992) showed that the values for the Ribéreau-Gayon and Stonestreet and Somers and Evans methods were always higher than those obtained by HPLC. Their reasoning was that HPLC measures only free anthocyanins, while the other two methods also evaluate a part of the polymers that is sensitive to the effect of $\mathrm{pH}$ and bisulphate bleaching.

\section{CONCLUSIONS}

The metabolic pathways in a living organism like a plant are phenomenal, and it is now evident that one metabolite leads into another metabolic pathway. The pathways in grapevines start with photosynthesis as soon as the buds start budding. Photosynthesis is the food factory of the vine, but carbohydrates manufactured by these factories will also be used in subsequent pathways until the synthesis of phenols and anthocyanins.

As these phenols and anthocyanins are synthesised, they are translocated to the berry, where they become very important to the winemaker. The winemaker must use different tools to extract the phenols and anthocyanins into the wine. The different tools that are at the winemaker's disposal vary from maceration techniques and thermovinification to the use of pectolytic enzymes. Each of these tools has its own advantages and disadvantages, and the choice which to use will depend on the market for which the wine is intended.

Quality measurements are of paramount importance, so this review article has been divided into colorimetric analysis, gravitational analysis and precipitation analysis, as well as different ways to analyse colour in the wine. In the end it is of importance to the winemaker to know the different analytical tools at his or her disposal so that better choices can be made.

\section{LITERATURE CITED}

Adams, D.O. \& Scholz, R.C., 2007. Tannins - the problem of extraction. In: Blair, R., Williams, P. \& Pretorius, S. (eds). 13th Australian Wine Industry Technical Conference, 28 July to 2 August 2007, Adelaide, South Australia. pp. $160-164$.

Álvarez, I., Aleixandre, J.L., Garćia, M.J., Lizama, V. \& AleixandreTudó, J.L., 2009. Effect of the prefermentative addition of copigments on the polyphenolic composition of Tempranillo wines after malolactic fermentation. Eur. Food Res. Techn. 228, 501-510.

Archer, E. \& Hunter, J.J., 2004. Vine balance: Its importance to successful cultivation. Wynboer Technical Yearbook 2004/5, 60-66.

Arnous, A. \& Meyer, A.S., 2010. Discriminated release of phenolic substances from red wine grape skins (Vitis vinifera $\mathrm{L}$.) by multi component enzyme treatment. Biochem. Eng. J. 49(1), 68-77.

Baiano, A., Terracone, C., Gambacorta, G. \& La Notte, E., 2009. Phenolic content and antioxidant activity of Primitivo wine: Comparison among winemaking techniques. J. Food Sci. 74(3), 258-267.

Bautista-Ortín, A.B., Martínez-Cutillas, A., Ros-García, J.M., López-Roca, J.M. and Gómez-Plaza, E., 2005. Improving colour extraction and stability in red wines: The use of maceration enzymes and enological tannins. Intern. J. Food Sci. Techn. 40, 867-878.

Bisson, L.F., 2001. Optimal grape maturity. Practical Winery and Vineyard July/Aug, 32.

Bogs, J., Downey, M.O., Harvey, J.S., Ashton, A.R., Tanner, G.J. \& Robinson, S.P., 2005. Proanthocyanidin synthesis and expression of genes encoding leucoanthocyanidin reductase and anthocyanidin reductase in developing grape berries and grapevine leaves. Plant Physiol. 139(2), 652663.

Bogs, J., Jaffé, F.W., Takos, A.M., Walker, A.R. \& Robinson, S.P., 2007. The grapevine transcription factor VvMYBPA1 regulates proanthocyanidins synthesis during fruit development. Plant Physiol. 143(3), 1347-1361.

Boss, P.K., Davies, C. \& Robinson, S.P., 1996. Anthocyanin composition and anthocyanin pathway gene expression in grapevine sports differing in berry skin colour. Austr. J. Grape Wine Res. 2, 163-170.

Boulton, R., 2001. The copigmentation of anthocyanins and its role in the color of red wine: A critical review. Am. J. Enol. Vitic. 52(2), 67-87.

Burger, J. \& Deist, J., 1981 (1st ed.). Wingerdbou in Suid-Afrika. TrioRand/S.A. Litho, Pretoria.

Butler, L.G., Price, M.L. \& Brotherton, J.E., 1982. Vanillin assay for proanthocyanidins (condensed tannins): Modification of the solvent for estimation of the degree of polymerization. J. Agric. Food Chem. 30, $1087-$ 1089.

Castañeda-Ovando, A., De Lourdes Pacheco-Hernández, Ma., Elena PáezHernández, Ma., Rodríguez, J.A. \& Galán-Vidal, C.A., 2009. Chemical studies of anthocyanins: A review. Food Chem. 113, 859-871.

Chen, M. \& Zhang, Y., 2008. Tracking the molecular evolution of photosynthesis through characterization of atomic contents of the photosynthetic units. Photosynth. Res. 97, 255-261.

Chorti, E., Guidoni, S., Ferrandino, A. \& Novello, V., 2010. Effect of different cluster sunlight exposure levels on ripening and anthocyanin accumulation in Nebbiolo grapes. Am. J. Enol. Vitic. 61(1), 23-30.

Coombe, B.G., 1992. Research on development and ripening of the grape berry. Am. J. Enol. Vitic. 43(1), 101-110. 
Coombe, B.G., 1995. Adoption of a system for identifying grapevine growth stages. Austr. J. Grape Wine Res. 1, 100-110.

Corder, R., 2007. The red wine diet. New York: Avery.

De Beer, D., Harbertson, J.F., Kilmartin, P.A., Roginsky, V., Barsukova, T., Adams, D.O. \& Waterhouse, A.L., 2004. Phenolics: A comparison of diverse analytical methods. Am. J. Enol. Vitic. 55(4), 389-400.

Dokoozlian, N.K. \& Kliewer, W.M., 1996. Influence of light on grape berry growth and composition varies during fruit development. J. Am. Soc. Hort. Sci. 121(5), 869-874.

Downey, M.O., Harvey, J.S. \& Robinson, S.P., 2003. Analysis of tannins in seeds and skins of Shiraz grapes throughout berry development. Austr. J. Grape Wine Res. 9, 15-27.

Etaio, I., Elortondo, F.J.P., Albisu, M., Gaston, E., Ojedo, M. \& Schlich, P., 2008. Effect of winemaking process and addition of white grapes on the sensory and physicochemical characteristics of young red wines. Austr. J. Grape Wine Res. 14, 211-222.

Ferrer, J.-L, Austen, M.B., Stewart C. Jr. \& Noel, J.P., 2008. Structure and function of enzymes involved in the biosynthesis of phenylpropanoids. Plant Physiol. Bioch. 46, 356-370.

Folin, O. \& Denis, W., 1912. On phosphotungstic-phosphomolybdic compounds as colour reagents. J. Biol. Chem. 12, 239-243.

Folin, O. \& Ciocalteu, V., 1927. On tyrosine and tryptophan determinations in protein. J. Biol. Chem. 73(2), 627-650.

Gawel, R., 1998. Red wine astringency: A review. Austr. J. Grape Wine Res. 4, 74-95.

Geny, L., Saucier, C., Bracco, S., Daviaud, F. \& Glories, Y., 2003. Composition and cellular localization of tannin in grape seeds during maturation. J. Agric. Food Chem. 51(27), 8051-8054

Gil-Muñoz, R., Moreno-Pérez, A., Vila-López, R., Fernández-Fernández, J.I., Martínez-Cutillas, A. \& Gómez-Plaza, E., 2009. Influence of low temperature prefermentative techniques on chromatic and phenolic characteristics of Shiraz and Cabernet Sauvignon wines. Eur. Food Res. Technol. 228, 777-788.

Giner-Chavez, B.I., Van Soest, P.J., Robertson, J.B., Lascano, C., Reed, J.D. \& Pell, A.N., 1997. A method for isolating condensed tannins from crude plant extracts with trivalent ytterbium. J. Sci. Food Agric. 74, 359-368.

Glories, Y., 1984a. La couleur des vins rouges 1: les equilibres des anthocyanes et des tanins. Connaissance Vigne Vin 18(3), 195-217.

Glories, Y., 1984b. La couleur des vins rouges 2: mesure origine et interpretation. Connaissance Vigne Vin 18(4), 253-271.

Gómez-Míguez, M. \& Heredia, F.J., 2004. Effect of the maceration technique on the relationships between anthocyanin composition and objective color of Syrah wines. J. Agric. Food Chem. 52(16), 5117-5123.

Gómez-Plaza, E., Gil-Muñoz, R., López-Roca, J.M. \& Martínez, A., 2000. Color and phenolic compounds of a young red wine: Influence of wine making techniques, storage temperature and length of storage time. J. Agric. Food Chem. 48(3), 736-741.

Gómez-Plaza, E., Gil-Muñoz, R., López-Roca, J.M., Martínez-Cutillas, A. \& Fernández-Fernández, J.I., 2001. Phenolic compounds and color stability of red wines: Effect of skin maceration time. Am. J. Enol. Vitic. 52(3), 266270

González-Neves, G., Gil, G. \& Barreiro, L., 2008. Influence of grape variety on the extraction of anthocyanins during the fermentation on skins. Eur. Food Res. Technol. 226(6), 1349-1355.
Guérin, L., Sutter, D.H., Demois, A., Chereau, M. \& Trandafir, G., 2009. Determination of activity profiles of the main commercial enzyme preparations used in winemaking. Am. J. Enol. Vitic. 60(3), 322-331.

Hagerman, A.E., 2002. Tannin handbook. Department of Chemistry \& Biochemistry, Miami University, Miami.

Hagerman, A.E. \& Butler, L.G., 1978. Protein precipitation method for the quantitative determination of tannin. J. Agric. Food Chem. 26(4), 809-812.

Harbertson, J.F. \& Spayd, S., 2006. Measuring phenolics in the winery. Am. J. Enol. Vitic. 57(3), 280-288.

Harbertson, J.F., Kennedy, J.A. \& Adams, D.O., 2002. Tannins in skins and seeds of Cabernet Sauvignon, Shiraz and Pinot noir berries during ripening. Am. J. Enol. Vitic. 53(1), 54-59.

Harbertson, J.F., Picciotto, E.A. \& Adams, D.O., 2003. Measurement of polymeric pigments in grape berry extracts and wines using a protein precipitation assay combined with bisulfate bleaching. Am. J. Enol. Vitic. 54(4), 301-306

Hardie, W.J. \& Considine, J.A., 1976. Response of grapes to water deficit stress in particular stages of development. Am. J. Enol. Vitic. 27(2), 55-61.

Herderich, M.J. \& Smith, P.A., 2005. Analysis of grape and wine tannins: Methods, applications and challenges. Austr. J. Grape Wine Research. 11, 205-214.

Herderich, M.J., Bell, S.-J., Holt, H., Ristic, R., Birchmore, W., Thompsons, K. \& Iland, P.G., 2001. Grape maturity and tannins: The impact of viticultural treatments on grape and wine tannins. In: Blair, R., Williams, P and Pretorius, S. (eds). 12th Australian Wine Industry Technical Conference. 24 - 29 July 2004, Melbourne, Victoria. Pp. 79-84.

Iland, I., Ewart, A., Sitters, J., Markides, A. \& Bruer, N., 2000. Techniques for chemical analysis and quality monitoring during winemaking. Patrick Iland Wine Promotions, Campbelltown.

Jaakola, J., Määttä, K., Pirttilä, A.M., Törrönen, R., Kärenlampi, S. \& Hohtola, A., 2002. Expression of genes involved in anthocyanin biosynthesis in relation to anthocyanin, proanthocyanidins and flavonols levels during bilberry fruit development. Plant Physiol. 130, 729-739.

Jackson, D.I. \& Lombard, P.B. 1993. Environmental and management practices affecting grape composition and wine quality: A review. Am. J. Enol. Vitic. 44(4), 409-430.

Jackson, R.S., 1994. Wine science: Principles and application. Academic Press., San Diego, United States.

Joscelyne, V. \& Ford, C.M., 2008. Consequences of extended maceration for red wine colour and phenolics. Unpublished report UA 05/03. Grape and Wine Research \& Development Corporation, University of Adelaide.

Kennedy, J.A., Matthews, M.A. \& Waterhouse, A.L., 2000a. Changes in grape seed polyphenols during fruit ripening. Phytochem. 55, 77-85.

Kennedy, J.A., Troup, G.J., Pilbrow, J.R., Hutton, D.R., Hewitt, D., Hunter, C.R., Ristic, R., Iland, P.G. \& Jones, G.P., 2000b. Development of seed polyphenols in berries from Vitis vinifera L cv. Shiraz. Austr. J. Grape Wine Res. 6, 244-254

Kennedy, J.A., Hayasaka, Y., Vidal, S., Waters, E.J. \& Jones, G.P., 2001. Composition of grape skin proanthocyanidins at different stages of berry development. J. Agric. Food Chem. 49(11), 5348-5355.

Kruger, N.J. \& Von Schaewen, A., 2003. The oxidative pentose phosphate pathway: Structure and organization. Curr. Opin. Plant Biol. 6, 236-246.

Lavee, S. \& May, P., 1997. Dormancy of grapevine buds - facts and speculation. Austr. J. Grape Wine Res. 3, 31-46.

Letaief, H., Rolle, L., Zeppa, G. \& Gerbi, V., 2008. Assessment of grape skin hardness by a puncture test. J. Sci. Food Agric. 88, 1567-1575. 
Levengood, J. \& Boulton, R., 2004. The variation in the color due to copigmentation in young Cabernet Sauvignon wines. In: Waterhouse, A.L. \& Kennedy, J.A. (eds.). Red wine color: Exploring the mysteries. ACS Symposium. Ser. 886. Am. Chem. Soc., Washington, DC. pp $35-52$.

Liang, Z., Wua, B., Fan, P., Yang, C., Duan, W., Zheng, X., Liu, C. \& Li, S., 2008. Anthocyanin composition and content in grape berry skin in Vitis germplasm. Food Chem. 111, 837-844.

Lorenzo, C., Pardo, F., Zalacain, A., Alonso, G.L. \& Salinas, M.R., 2005 Effect of red grapes co-winemaking in polyphenols and color of wines. J. Agric. Food Chem. 53(19), 7609-7616.

Lowe, E.J., Oey, A. \& Turner, T.M., 1976. Gasquet thermovinification system perspective after two years operation. Am. J. Enol. Vitic. 27(3), 130133.

Makkar, H.P.S., 1989. Protein precipitation methods for quantitation of tannins: A review. J. Agric. Food Chem. 37(4), 1197-1202.

Marques, M.R., Pereira, J.H., Oliveira, J.S., Basso, L.A., De Azevedo Jr., W.F., Santos, D.S. \& Palma, M.S., 2007. The inhibition of 5-enolpyruvylshikimate-3-phosphate synthase as a model for development of novel antimicrobials. Curr. Drug Targets 8, 445-457.

Matthews, M.A. \& Anderson, M.M., 1988. Fruit ripening in Vitis vinifera L: Responses to seasonal water deficits. Am. J. Enol. Vitic. 39(4), 313-320.

McGovern, P.E., Underhill, A.P., Fang, H., Luan, F., Hall, G.R., Yu, H., Wang, C-S., Cai, F., Zhao, Z. \& Feinman, G.M., 2005. Chemical identification and cultural implications of a mixed fermented beverage from late prehistoric China. Asian Perspectives 44(2), 249-275.

McMahon, H.M., Zoecklein, B.W. \& Jasinski, Y.W., 1999. The effects of prefermentation maceration temperature and percent alcohol $(\mathrm{v} / \mathrm{v})$ at press on the concentration of Cabernet Sauvignon grape glycosides and glycoside fractions. Am. J. Enol. Vitic. 50(4), 385-390.

Monagas, M., Bartolomé, B. \& Gómez-Cordovés, C., 2005. Updated knowledge about the presence of phenolic compounds in wine. Crit. Rev. Food Sci. 45, 85-118.

Mori, K., Sugaya, S. \& Gemma, H., 2005. Decreased anthocyanin biosynthesis in grapes berries grown under elevated night temperature conditions. Sci. Hortic. 105, 319-330.

Moris, L.S. \& Silber, J.K., 2006. New tannin assay for winemakers. Wine Business Monthly February.

Ortega-Regules, A., Romero-Cascales, I., Ros-Garćia, J.M., López-Roca, J.M. \& Gómez-Plaza, E., 2006. A first approach towards the relationship between grape skin cell wall composition and anthocyanin extractability. Anal. Chim. Acta 563, 26-32.

Parenti, A., Spugnoli, P., Calamai, L., Ferrari, S. \& Gori, C., 2004. Effects of cold maceration on red wine quality from Tuscan Sangiovese grapes. Eur. Food Res. Technol. 218, 361-366.

Pastor del Rio, J.L. \& Kennedy, J.A., 2006. Development of proanthocyanidins in Vitis vinifera $\mathrm{L}$ cv. Pinot noir grapes and extraction into wine. Am. J. Enol. Vitic. 57(2), 125-132.

Porter, L.J., Hrstich, L.N. \& Chan, B.G., 1986. The conversion of procyanidins and prodelphinidins to cyanidin and delphinidin. Phytochemistry 25(1), 223-230.

Pretorius, I.S., Bauer, F.F., Lambrecht, M.G., Van Rensburg, P. \& Vivier, M.A., 1998. Potential application of gene technology in winemaking. In: Blair, R.J., Sas, A.N., Hayes, P.F. \& and Høj, P.B (eds). 10th proceedings of the Australia Wine Industry Technical Conference. Sydney, New South Wales, Australia. Pp. 129-133.

Price, M.L. \& Butler, L.G., 1977. Rapid visual estimation and spectrophotometric determination of tannin content of sorghum grain. J. Agric. Food Chem. 25(6), 1268-1277.
Revilla, I. \& González-San José, M.L., 2003. Addition of pectolytic enzymes: An enological practice which improves the chromaticity and stability of red wines. Int. J. Food Sci. Tech. 38, 29-36.

Ribereau-Gayon, P., Dubourdieu, D., Doneche, B. \& Lonvaud, A., 2000 (2nd ed.). Handbook of enology. Volume 1. John Wiley \& Sons, Ltd.

Río Segade, S., Rolle, L., Gerbi, V. \& Orriols, I., 2008. Phenolic ripeness assessment of grape skin by texture analysis. J. Food Comp. Anal. 21, 644649.

Ristic, R., Downey, M.O., Iland, P.G., Bindon, K., Francis, I.L., Herderich, M. and Robinson, S.P., 2007. Exclusion of sunlight from Shiraz grapes alters wine colour, tannin and sensory properties. Austr. J. Grape Wine Res. $13,53-65$.

Rivas-Gonzalo, J.C., Gutierrez, Y., Hebrero, E. \& Santos-Buelga, C., 1992. Comparisons of methods for the determination of anthocyanins in red wines. Am. J. Enol. Vitic. 43(2), 210-214.

Rolle, L., Torchio, F., Zeppa, G. \& Gerbi, V., 2009. Relationship between skin break force and anthocyanin extractability at different ripening stages. Am. J. Enol. Vitic. 60(1), 93-97.

Romero-Cascales, I., Ortega-Regules, A., López-Roca, J.M., FernándezFernández, J.I. \& Gómez-Plaza, E., 2005. Differences in anthocyanin extractability from grapes to wine according to variety. Am. J. Enol. Vitic. $56(3), 212-219$

Sacchi, K.L., Bisson, L. \& Adams, D.O., 2005. A review of the effect of winemaking techniques on phenolic extraction in red wines. Am. J. Enol. Vitic. 56(3), 197-206.

Sarneckis, C.J., Dambergs, R.G., Jones, P., Mercurio, M., Herderich, M.J. \& Smith, P.A., 2006. Quantification of condensed tannins by precipitation with methyl cellulose: development and validation of an optimized tool for grape and wine analysis. Austr. J. Grape Wine Res. 12, 39-49.

Schofield, P., Mbugua, D.M. \& Pell, A.N., 2001. Analysis of condensed tannins: A review. Anim. Feed Sci. Tech. 91, 21-40.

Scudamore-Smith, P.D., Hooper, R.L. \& McLaran, E.D., 1990. Color and phenolic changes of Cabernet Sauvignon wine made by simultaneous yeast/ bacterial fermentation and extended pomace contact. Am. J. Enol. Vitic. 41(1), 57-67.

Seddon, T.J. \& Downey, M.O., 2008. Comparison of analytical methods for the determination of condensed tannins in grape skins. Austr. J. Grape Wine Res. 14, 54-61.

Singleton, V.L., Orthofer, R. \& Lamuela-Raventós, R.M., 1999. Analysis of total phenols and other oxidation substrates and antioxidants by means of Folin-Ciocalteu reagent. Method Enzymol. 299, 152-178.

Somers, E. \& Evans, M.E., 1974. Wine quality: Correlations with colour density and anthocyanin equilibria in a group of young red wines. J. Sci. Food Agric. 25, 1369-1379.

Somers, T.C. \& Evans, M.E., 1986. Evolution of red wines 1. Ambient influences on colour composition during early maturation. Vitis 25, 31-39.

Souquet, J., Cheynier, V., Brossaud, F. \& Moutounet, M., 1996. Polymeric proanthocyanidins from grape skins. Phytochemistry 43(2), 509-512.

Sun, B., Ricardo-da-Silva, J.M. \& Spranger, I., 1998. Critical factors of vanillin assay for catechins and proanthocyanidins. J. Agric. Food Chem. $46(10), 4267-4274$

Timberlake, C.F. \& Bridle, P., 1976. Interactions between anthocyanins, phenolic compounds and acetaldehyde and their significance in red wine. Am. J. Enol. Vitic. 27(3), 97-105.

Vasserot, Y., Caillet, S. \& Maujean, A., 1997. Study of anthocyanin adsorption by yeast lees: Effect of some physicochemical parameters. Am. J. Enol. Vitic. 49(4), 433-437. 
Versari, A., Boulton, R. \& Parpinello, G.P., 2008. A comparison of analytical methods for measuring the color components of red wines. Food Chem. $106,397-402$.

Voet, D. \& Voet J.G., 2004 (3rd ed.). Biochemistry. John Wiley \& Sons Inc. Wagener, G.W.W., 1981. The effect of different thermovinification systems on red wine quality. Am. J. Enol. Vitic. 32(3), 179-184.

White, T., 1957. Tannins: Their occurrence and significance. J. Sci. Food. Agric. 8, 377-385.

Winkel-Shirley, B., 2001. Flavonoid biosynthesis: A colourful model for genetics, biochemistry, cell biology and biotechnology. Plant Physiol. $126(2), 485-493$.
Winkler, A.J., 1965 (2nd ed.). General viticulture. University of California Press, Berkeley, USA.

Winter, E., Whiting, J. \& Rousseau, J., 2004. Wine grape berry sensory assessment in Australia. Adelaide: Winetitles.

Zimmer, A., Joslin, W.S., Lyon, M.L., Meier, J. \& Waterhouse, A.L., 2002. Maceration variables affecting phenolic composition in commercial-scale Cabernet Sauvignon winemaking trails. Am. J. Enol. Vitic. 53(2), 93-98. 